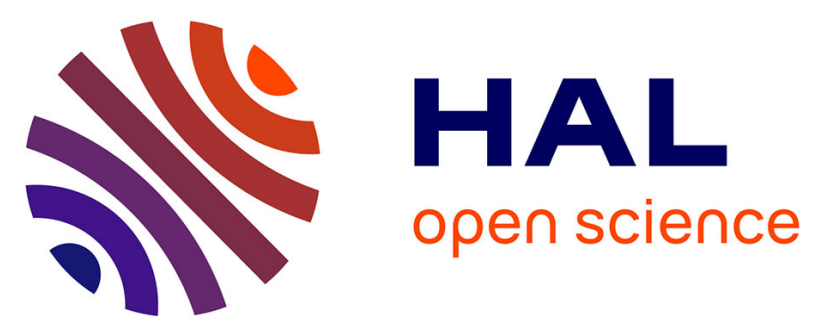

\title{
Electronic states of neutral and ionized tetrahydrofuran studied by VUV spectroscopy and ab initio calculations
}

\author{
A. Giuliani, Paulo Limão-Vieira, D. Duflot, A. R. Milosavljevic, B. P.
}

Marinkovic, S. V. Hoffmann, N. J. Mason, J. Delwiche, M.-J. Hubin-Franskin

\section{- To cite this version:}

A. Giuliani, Paulo Limão-Vieira, D. Duflot, A. R. Milosavljevic, B. P. Marinkovic, et al.. Electronic states of neutral and ionized tetrahydrofuran studied by VUV spectroscopy and ab initio calculations. The European Physical Journal D: Atomic, molecular, optical and plasma physics, 2009, 51 (1), pp.97-108. 10.1140/epjd/e2008-00154-7 . hal-00880769

\section{HAL Id: hal-00880769 \\ https://hal.science/hal-00880769}

Submitted on 5 Dec 2017

HAL is a multi-disciplinary open access archive for the deposit and dissemination of scientific research documents, whether they are published or not. The documents may come from teaching and research institutions in France or abroad, or from public or private research centers.
L'archive ouverte pluridisciplinaire HAL, est destinée au dépôt et à la diffusion de documents scientifiques de niveau recherche, publiés ou non, émanant des établissements d'enseignement et de recherche français ou étrangers, des laboratoires publics ou privés. 


\title{
Electronic states of neutral and ionized tetrahydrofuran studied by VUV spectroscopy and ab initio calculations
}

\author{
A. Giuliani ${ }^{1,2, *}$, P. Limão-Vieira ${ }^{3,4}$, D. Duflot ${ }^{5}$, A. R. Milosavljevic ${ }^{6}$, B. P. Marinkovic ${ }^{6}$, S. \\ V. Hoffmann ${ }^{7}$, N. Mason ${ }^{4}$, J. Delwiche ${ }^{8}$, M.-J. Hubin Franskin ${ }^{8}$ \\ ${ }^{1}$ DISCO beamline, Synchrotron Soleil, L’Orme des Merisiers, Saint-Aubin, 91192 Gif-sur-Yvette, France \\ ${ }^{2}$ Cepia, Institut National de la Recherche Agronomique (INRA), BP 71627, 44316 Nantes Cedex 3, France \\ ${ }^{3}$ Laboratório de Colisões Atómicas e Moleculares, CEFITEC, Departamento de Física, Universidade Nova de \\ Lisboa, 2829-516 Caparica, Portugal \\ ${ }^{4}$ Centre of Molecular and Optical Sciences, Department of Physics and Astronomy, The Open University, \\ Walton Hall, Milton Keynes, MK7 6AA, UK \\ ${ }^{5}$ Laboratoire de Physique des Lasers, Atomes et Molécules (PhLAM), UMR CNRS 8523, Centre d'Études et de \\ Recherches Lasers et Applications (CERLA, FR CNRS 2416), Université des Sciences et Technologies de Lille, \\ F-59655 Villeneuve d'Ascq Cedex, France \\ ${ }^{6}$ Laboratory for atomic collision processes, Institute of Physics, Pregrevica118, 11080 Belgrade, Serbia \\ ${ }^{7}$ Institute for Storage Ring Facilities, University of Aarhus, Ny Munkegade, DK-8000, Aarhus C, Denmark \\ ${ }^{8}$ Laboratoire de Spectroscopie d'Électrons diffusés, Université de Liège, Institut de Chimie-Bât. B6c, B-4000 \\ Liège 1, Belgium \\ *e-mail: alexandre.giuliani@synchrotron-soleil.fr
}

\begin{abstract}
The electronic spectroscopy of isolated tetrahydrofuran (THF) in the gas phase has been investigated using high-resolution photoabsorption spectroscopy in the 5.8-10.6 eV with absolute cross section measurements derived. In addition, an electron energy loss spectrum was recorded at $100 \mathrm{eV}$ and $10^{\circ}$ over the 5-11.4 eV range. The $\mathrm{He}(\mathrm{I})$ photoelectron spectrum was also collected to quantify ionisation energies in the 9-16.1 eV spectral region. These experiments are supported by the first high-level ab initio calculations performed on the excited states of the neutral molecule and on the ground state of the positive ion. The excellent agreement between the theoretical results and the measurements allows us to solve several discrepancies concerning the electronic state spectroscopy of THF. The present work reconsiders the question of the lowest energy conformers of the molecule and its population distribution at room temperature.
\end{abstract}

PACS. $33.20 . \mathrm{Ni}-33.60 .+\mathrm{q}-32.80 . \mathrm{Ee}-31.15 . \mathrm{A}--87.53 . \mathrm{j}$ 


\section{Introduction}

Tetrahydrofuran (THF) is a five membered heterocyclic ring that is often used as a chemical and molecular model for the (deoxy)ribose ring in nucleic acids. In the past ten years considerable research has been dedicated to the study of the spectroscopy and collisional interactions with biomolecules such as THF - either deposited as thin films or in the gas phase. The motivation for much of this work has been in relation to the study of radiation damage to biomolecules since it is known that a large amount of the energy deposited in biological media by ionising radiation is channelled into biomolecules such as DNA and the lipids forming cellular membranes. In particular ionising radiation liberates large numbers of low energy secondary electrons [1]. These secondary electrons, despite having energies below the ionization threshold, can induce significant amounts of both single and double strand breaks within the cellular DNA [2] in turn providing the origin of mutations or inducing cellular death [3].

Low energy electrons may also excite biomolecular targets through inelastic collisions and populate electronically excited states which may subsequently decay with the production of 'radicals' whose chemical reactivity may strongly influence the local site chemistry. A detailed understanding of the electronic state spectroscopy of the molecular constituents of DNA are therefore necessary if we are to develop a comprehensive understanding of radiation induced damage in DNA at a molecular level. However since the nucleosides and nucleotides comprising DNA are solids at room temperature it has, to date, proven difficult to measure absolute photoabsorption cross sections for these compounds and to date there are only a few spectroscopic studies of such molecules. THF provides a good analogue for the (deoxy)ribose nucleic acids and therefore in recent years has been the subject of several experimental and theoretical studies [4-15]. However severe discrepancies concerning the spectroscopy of THF remain.

THF is a puckered molecule supporting several internal motions of out-of-plane ring vibrations, called pseudorotation [16]. The molecule may adopt several different conformations, Fig. 1, all of which appear to be connected along the pseudorotation path as a function of the pseudorotation angle $\phi$. A similar type of ring deformation is known to occur in the nucleosides and nucleotides and is closely related to higher order structure in the nucleic acids like DNA and RNA [17]. The preferred conformation of the isolated molecule in the gas phase is still debated, despite several experimental [18-21] and theoretical studies to 
clarify the situation [16,21-24]. Recently, Yang at al. suggested that the most populated conformer could be obtained from Electron Momentum Spectroscopy (EMS) [25].

The first study of the electronic state spectroscopy of THF was performed by Picket et al. [26], who measured the VUV photoabsorption spectrum for the first time. This early work reported two electronic transitions at $51440 \mathrm{~cm}^{-1}(6.378 \mathrm{eV})$ and $55640 \mathrm{~cm}^{-1}(6.899 \mathrm{eV})$. Subsequent work by Hernandez [27] confirmed the electronic transitions of Pickett et al. [26]. A vibrational analysis of structure observed in the VUV spectrum was performed and four Rydberg series identified. Subsequently Davidson et al. [28] contested these pioneering investigations. They suggested the lowest energy optically active transition to be the $n \rightarrow 3 s$ transition [28] at $6.03 \mathrm{eV}$. A complex vibrational structure was reported involving multiple excitations and de-excitation of the pseudo-rotation mode with frequencies ranging from 60 to $260 \mathrm{~cm}^{-1}$ [28]. Above $6.3 \mathrm{eV}$ the band broadens and a second electronic transition was suggested with vibrational frequencies around $200 \mathrm{~cm}^{-1}$. The presence of such an unexpected transition in this energy region was commented upon by Robin [29]. Tam and Brion have recorded the first electron energy loss spectrum in dipolar excitation conditions of the molecule [30]. Their analysis of the spectral band was based on derived term values. A Rydberg series analysis by Doucet et al [31] reported a single ns series $(\delta=0.94)$, two np series $(\delta=0.64$ and 0.52$)$ and a single nd series $(\delta=0.08)$. Their assignment of the $n=3$ member was in agreement with the previous work, but interestingly, their vibrational analysis of the first spectral band did not involve a second electronic origin. Bremner et al. [32] reexamined the VUV photoabsorption spectrum of THF extending the excitation energy range up to the LiF cut off at $11.8 \mathrm{eV}$ allowing further Rydberg series to be analysed.

In this paper we present a combined theoretical and experimental study of the ground and excited states of both the neutral THF molecule and its cation. We believe that this work represents the highest resolution photoabsorption and photoelectron data currently available. For the first time, the neutral and ionic excited states are studied theoretically using high-level $a b$ initio methods. Through a combination of these theoretical and experimental results we are then able to discuss previous discrepancies concerning the nature of the lowest energy spectral band in the photoabsorption and reassign the broad features at higher energies. This, in turn, leads us to address the question of the lowest energy conformers of the molecule and to question the claims of Yang et al. [25] following their EMS study. Hitherto, the electronic 
spectra of THF recorded at room temperature were interpreted on the basis of a single geometry. We show in the following that a better description of the electronic spectroscopy of the molecule is gained by considering the two lowest energy conformers.

\section{Methods}

\subsection{Photoabsorption spectroscopy}

The high-resolution VUV photoabsorption measurements were performed using the ASTRID - UV1 beam line at the Institute for Storage Ring Facilities (ISA), University of Aarhus, Denmark. A detailed description of the apparatus can be found elsewhere [33], so only a brief description will be given here. A toroidal dispersion grating is used to select the synchrotron radiation with a FWHM wavelength resolution of approximately $0.075 \mathrm{~nm}$. The synchrotron radiation passes through the static gas sample at room temperature. A photo-multiplier is used to detect the transmitted light. For wavelengths below $200 \mathrm{~nm}$ a flow of He gas is flushed through the small gap between the photomultiplier and the exit window of the gas cell to prevent any absorption by air in the VUV range of the spectrum. A LiF entrance window acts as an edge filter for higher order radiation restricting the photoabsorption measures to below $10.8 \mathrm{eV}(115 \mathrm{~nm})$. The grating itself provides a maximum wavelength (lower energy limit) of $320 \mathrm{~nm}(3.9 \mathrm{eV})$. The sample pressure is measured by a Baratron capacitance gauge. To avoid any saturation effects sample pressures were chosen such that the transmitted flux was $>10 \%$ of the incident flux.

Gas transmission results are compared to a background scan recorded with an evacuated cell. Absolute photoabsorption cross sections may then be calculated using the Beer-Lambert law:

$$
I_{t}=I_{0} \exp (-n \sigma x),
$$

where $I_{t}$ is the intensity of the light transmitted through the gas sample, $I_{0}$ is that through the evacuated cell, $n$ is the molecular number density of the sample gas, $\sigma$ is the absolute photoabsorption cross section and $x$ is the absorption path length $(25 \mathrm{~cm})$. The accuracy of the absolute cross-section is estimated to be better than $5 \%$.

\subsection{Photoelectron spectroscopy}

$\mathrm{He}(\mathrm{I})(21.22 \mathrm{eV})$ photoelectron spectra of THF were recorded at the Universite de Liège, Belgium. The apparatus has been described in detail previously [34]. Briefly, the spectrometer consists of a $180^{\circ}$ cylindrical electrostatic analyser with a mean radius of $5 \mathrm{~cm}$. The analyser 
is used in constant energy pass mode. The incident photons are produced by a D.C. discharge in a two-stage differentially pumped lamp. The energy scale was calibrated using argon lines $\left({ }^{2} \mathrm{P}_{3 / 2}=15.760 \mathrm{eV}\right.$ and $\left.{ }^{2} \mathrm{P}_{1 / 2}=15.937 \mathrm{eV}\right)[35,36]$ and the resolution of the present spectrum is measured from the full width half maximum of the Ar peaks to be $50 \mathrm{meV}$, in presence of THF. The intensities in the spectrum were corrected for the transmission of the analyzing system. The data reported here are the sums of many individual spectra. This procedure allows us to obtain a good signal-to-noise ratio while keeping the pressure in the spectrometer at very low level $\left(<5 \times 10^{-6}\right.$ mbar $)$. The accuracy of the energy scale is estimated to be \pm 2 meV.

\subsection{Electron energy loss spectroscopy}

The electron energy loss spectra of THF have been measured at the Institute of Physics, Belgrade, using a cross beam experimental setup which has been described recently [37]. Briefly, a non-monochromated electron beam produced by an electron gun crosses perpendicularly a molecular beam produced by a non-magnetic stainless steel needle. The scattered electrons are retarded and focused into a double cylindrical mirror energy analyzer (DCMA). After being selected by energy, the electrons are focused by a three-element cylindrical lens into a single channel multiplier, working in a single counting mode. The highest energy resolution was limited by the initial thermal spread of incident electrons to be about $0.5 \mathrm{eV}$. The accuracy of the incident electron energy was determined to be $\pm 0.4 \mathrm{eV}$ by observing a threshold for $\mathrm{He}^{+}$ions yield. The electron gun can be rotated around the gas needle in the range of about $-40^{\circ}$ to $130^{\circ}$. The uncertainty of the angular scale was found to be better than $\pm 0.5^{\circ}$. The base pressure was about $3 \times 10^{-7}$ mbar and the operating pressure was about $6 \times 10^{-6}$ mbar. The electron energy loss measurements were performed in a constant pass energy mode, by ramping the retarding potential at the entrance of DCMA. The calibration of the energy loss scale has been obtained according to the position of the elastic peak. The measurements were performed in conditions that favor dipole-allowed transitions - small scattering angles $\left(10^{\circ}\right)$ and high incident energies $(100 \mathrm{eV})$, such that they may be directly compared with the high-resolution VUV optical measurements.

\subsection{The terahydrofuran sample}

The gas sample used in all the measurements was purchased from Sigma-Aldrich, with a minimum purity of $+99 \%$. The samples have been submitted to repeated freeze-pump-thaw cycles to remove the dissolved gases. 


\subsection{Ab initio calculations}

$A b$ initio calculations were used to determine vertical excitation energies of the electronic states using the EOM-CCSD [38] implemented in the MOLPRO programme [39]. The equilibrium geometry of the $\mathrm{C}_{2}$ and $\mathrm{C}_{\mathrm{s}}$ conformers is identical to the results of Rayón and Sordo [24] obtained at the MP2 level with the aug-cc-pVDZ basis set. In order to describe Rydberg states, diffuse functions (5s, 5p, 5d) taken from Kaufmann et al. [40] were added at the centre of the molecule. The ionisation energies were obtained with the Restricted Outer Valence Green's Function (ROVGF) method [41, 42], using the Gaussian03 package [43].

\section{Results and Discussion}

\subsection{Neutral ground state}

As mentioned in the introduction, the lowest energy structure of the molecule is still the subject of debate. Table 1 summarizes the literature results together with the present findings. According to the microwave spectroscopic studies of Mamleev et al. [20], supported by the recent experimental and theoretical work of Melnik et al. [21], the global minimum is found for the twisted $\mathrm{C}_{2}$ conformation. These findings are in sharp contrast with the previous results of Engerholm et al. [18] and of Meyer et al. [19], for whom the global minimum is very close to the envelope ${ }_{5} \mathrm{E}\left(\mathrm{C}_{1}\right)$ conformation. From a theoretical point of view Cadioli et al. [22] using HF and MP2 calculation found $\mathrm{C}_{2}, \mathrm{C}_{1}$ and $\mathrm{C}_{\mathrm{s}}$ in this increasing sequence stability. Han and Kang [23] reported at the HF and MP2 level of theory the twisted $\mathrm{C}_{2}$ conformations to be the most stable. Melnik et al. [21] carried out MP2/6-31+G(p,d) and B3LYP/6-31+G(p,d) calculations, which gave the twisted $\mathrm{C}_{2}$ as a global minimum in perfect agreement with their experimental results. $\mathrm{Wu}$ and Cremer also reported, at the MP2/cc-pVTZ and B3LYP/6$31 \mathrm{G}(\mathrm{p}, \mathrm{d})$ levels, the twisted ${ }_{1} \mathrm{E}$ geometry $\left(\mathrm{C}_{2}\right)$ to be the global minimum [16] lying $\sim 0.2$ $\mathrm{kcal} / \mathrm{mol}$ below the $\mathrm{C}_{\mathrm{s}}$ geometry. Recently, Rayón and Sordo [24] performed a detailed theoretical study at the MP2/aug-cc-pVTZ including anharmonic ZPE correction and suggested that the envelopes $\mathrm{C}_{\mathrm{s}}$ are the global minima structures. The authors estimated the energy difference between $\mathrm{C}_{\mathrm{s}}$ and $\mathrm{C}_{2}$ minima to be $46 \mathrm{~cm}^{-1}$ (i.e. $0.13 \mathrm{kcal} / \mathrm{mol}$ ) at the $\operatorname{CCSD}(\mathrm{T}) / / \mathrm{CBS}(\mathrm{MP} 2)$ level. Surprisingly, this theoretical finding is at variance with every previous result from microwave spectroscopy and from theoretical calculations as seen in Table 1. It is also worth noting that, as previously mentioned by Cadioli et al. [22], results from X-rays [44] and neutron diffraction [45] experiments are consistent with the $\mathrm{C}_{2}$ geometry, as seen from the values of dihedral angle involving the ring at supplementary 
information table 1. Rayón and Sordo [24] have pointed out that the potential energy surface (PES) is nearly flat, which makes the characterisation of geometries as the extrema along the pseudo-rotational coordinate a challenging task. The global shape of the PES was also found to be extremely dependent on the basis set used. Recently, from EMS experiments, Yang et al. [25] have claimed the $\mathrm{C}_{\mathrm{s}}$ geometry to be the most populated conformer of THF on the basis on better agreement of calculated orbital momentum distribution for the $\mathrm{C}_{\mathrm{s}}$ geometry with the experiment.

We have calculated the ground state geometry at the MP2 level of theory following Rayón and Sordo [24] for the $\mathrm{C}_{2 \mathrm{v}}, \mathrm{C}_{2}$ and $\mathrm{C}_{\mathrm{s}}$ isomers (the $\mathrm{C}_{1}$ isomer being neglected) using the augcc-pVDZ basis set. The results are compared with the available literature data [19,22$24,44,45]$ at supplementary information, table 1 . At this level, the $\mathrm{C}_{\mathrm{s}}$ geometry is a saddle point but with the larger aug-cc-pVTZ basis set $\mathrm{C}_{\mathrm{s}}$ and $\mathrm{C}_{2}$ are minima of the PES. Although the basis set has been found by Rayón and Sordo [24] to have important effects on the nature of the PES extremum, our use of the aug-cc-pVDZ basis set should have little influence on the electronic excitation energies, especially since most excited states are Rydberg in nature. Considering the Rayón and Sordo computed energy separation of $46 \mathrm{~cm}^{-1}$ for these two lowest energy conformers, it is very likely that at room temperature both isomers coexist. Indeed, a Boltzmann analysis at $298 \mathrm{~K}$ indicates that $\mathrm{C}_{2}$ and $\mathrm{C}_{\mathrm{s}}$ amount to $55.5 \%$ and $44.5 \%$ of the population, respectively. The $\mathrm{C}_{2 \mathrm{v}}$ geometry is excluded from the Boltzmann population analysis since a consensus has been reached in the literature, for which this geometry is a saddle point $[19,22-24,44,45]$ with two imaginary frequencies. We shall therefore consider in the following discussion the possible spectral signature from the $\mathrm{C}_{\mathrm{s}}$ and $\mathrm{C}_{2}$ conformers of THF.

The electronic configuration of THF in its electronic ground state and in the $\mathrm{C}_{2 \mathrm{v}}$ formalism is: $1 a_{1}^{2} 1 b^{2} 2 a_{1}^{2} 3 a_{1}^{2} 2 b_{1}^{2} 4 a_{1}^{2} 5 a_{1}^{2} 3 b_{1}^{2} 6 a_{1}^{2} 4 b_{1}^{2} 1 b_{2}^{2} 7 a_{1}^{2} 1 a_{2}^{2} 2 b_{2}^{2} 5 b_{1}^{2} 8 a_{1}^{2} 6 b_{1}^{2} 9 a_{1}^{2} 2 a_{2}^{2} 3 b_{2}^{2}: \quad \tilde{X}^{1} \mathrm{~A}_{1}$.

$\mathrm{C}_{2 \mathrm{v}}$ correlates unambiguously to the other lower geometries. In the $\mathrm{C}_{2}$ point group, the $\mathrm{C}_{2 \mathrm{v}} \mathrm{a}_{1}$ and $\mathrm{a}_{2}$ become $a$ and $b_{1}$ and $b_{2}$ correlate to $b$. For the $C_{s}$ geometry, $a_{1}$ and $b_{1}$ become $a^{\prime}$ and $a_{2}$ and $\mathrm{b}_{2}$ become a".

The molecule possesses 33 normal vibrations distributed into two irreducible subgroups $17 \mathrm{~A}+16 \mathrm{~B}$ in the $\mathrm{C}_{2}$ point group $[22,23,46,47]$. The literature data on the normal vibrational mode are shown in supplementary information table 2 together with the assignments from Lepage et al. [4]. 


\subsection{Neutral excited states}

Table 2 compares the calculated excited states transition for the two lowest energy geometries of THF, namely $\mathrm{C}_{\mathrm{s}}$ and $\mathrm{C}_{2}$, with the assignments made from the photoabsorption measurements. Figure 2 shows the photoabsorption spectrum recorded between $5.8 \mathrm{eV}$ and $10.7 \mathrm{eV}(2 \mathrm{a})$ and the electron energy loss spectra (EELS) up to $11.5 \mathrm{eV}(2 \mathrm{~b})$. Although measured at lower resolution, the EELS spectra agree well with the photoabsorption data for the band position. Our data also appears to be in very good agreement with the literature data of Davidson et al. [28] and Bremner et al. [32] in both energy position and absolute cross section, although our resolution is better than that of Bremner et al. [32]. The photoabsorption spectrum is composed of a low energy band peaking at $6.6 \mathrm{eV}$, on which very sharp features are superimposed. At $6.9 \mathrm{eV}$ a second band starts and extending up to $7.7 \mathrm{eV}$, peaking at 7.15 $\mathrm{eV}$ with a local maximum cross section of 12 Mbarn. This band also shows structure on its low energy side. It is followed by a third band up to $8.3 \mathrm{eV}$ on which sharper features are observed. From $8.3 \mathrm{eV}$, the cross section, superimposed with sharper features, rises almost monotonically up to the end of the present measurements.

\subsubsection{Lowest energy excited states}

3.2.1.1.The $3 \mathrm{~s}$ terms of the series converging to the ionic ground electronic state Figure 3(a) shows the lowest energy band spanning from 6.04 to $6.88 \mathrm{eV}$. This spectral region appears extremely structured. As discussed above, the assignments to be given to this band have been much debated in the literature and there is currently no agreement as to its classification. Davidson et al. [28], on the basis of careful vibrational analysis conducted at different sample temperatures, concluded that this band should be assigned to two electronic origins with their associated vibrational progressions. In contrast other authors reported a single electronic transition with heavy hot band structure. This absorption band, centred around $6.5 \mathrm{eV}$, which corresponds to a term value of $3.25 \mathrm{eV}$ is indicative of a $3 \mathrm{~s}$-type Rydberg state. Hence, the presence of two electronic origins was puzzling, as noted by Robin [29].

Our calculations (table 2) predict the lowest energy singlet excited state of the molecule to be the 3 s Rydberg state converging to the first ionic limit for every geometry considered. Vertical transition to this excited state is calculated at a noticeable lower energy $(6.357 \mathrm{eV})$ but with half the oscillator strength for the $C_{2}$ geometry than for the $C_{s}(6.608 \mathrm{eV})$. Hence, based on our theoretical results, we assign the first absorption band to the lowest energy 
transitions for the $\mathrm{C}_{2}$ and $\mathrm{C}_{\mathrm{s}}$ conformers, see Fig. 3(a). We have placed the $3 \mathrm{~s}\left(\mathrm{C}_{2}\right)$ adiabatic transition energy at $6.221 \mathrm{eV}$ in agreement with Davidson et al. [28]. The vibrational assignments are given in supplementary information table 3 . The vibrational structure may be rationalized in terms of a progression of $62.9 \mathrm{~cm}^{-1}(7.8 \mathrm{meV})$ corresponding to the excitation of the ring-puckering mode (table 1). We estimate the vertical energy for the $3 \mathrm{~s}\left(\mathrm{C}_{2}\right)$ transition to be around $6.3 \mathrm{eV}$. In agreement with Davidson et al. [28] we find a hot band system involving excitation of $v_{17}$, which wavenumber of $250.8 \mathrm{~cm}^{-1}(31.1 \mathrm{meV})$ agrees very well with the values reported for the ground state of $286 \mathrm{~cm}^{-1}(35.5 \mathrm{meV})$ (see table 3 and also in supplementary information).

The $3 \mathrm{~s}\left(\mathrm{C}_{\mathrm{s}}\right)$ 0-0 transition is placed at $6.353 \mathrm{eV}$ and appears accompanied by two long and overlapping progressions of $171 \mathrm{~cm}^{-1}(21.2 \mathrm{meV})$ and $237 \mathrm{~cm}^{-1}(29.38 \mathrm{meV})$ assigned to the ring-puckering modes $v_{33}$ and $v_{17}$, respectively (see table 3 and also in supplementary information). The $v_{33}$ progression was also reported by Davidson et al. [28] but with no further discussion.

3.2.1.2. The $3 p$ terms of the series converging to the ionic ground electronic state Figure 3(b) shows an enlargement of the 6.8 to $8.4 \mathrm{eV}$ band system. Our calculations predict excitations of the $3 \mathrm{p}$ members to be mostly responsible for this absorption band, in agreement with the previous work of Bremner et al. [32]. Again, the agreement between theory and experiment is excellent and allows a straightforward interpretation of this spectral region. The calculation predicts the $3 \mathrm{p}$ excitation for the $\mathrm{C}_{\mathrm{s}}$ geometry at $7.154 \mathrm{eV}$ with oscillator strength of 0.047 , which is very close to the maximum of the absorption band at $7.19 \mathrm{eV}$. This feature was assigned to excitation of a $3 p$ state by Bremner et al. [32]. The maximum of this band appears structured by less intense and sharp features, which are assigned to vibrational excitation accompanying this electronic transition. Analysis of this fine structure leads us to place the electronic origin at $7.134 \mathrm{eV}$. We identify a single progression of vibrational modes of $79.8 \mathrm{~cm}^{-1}(9.9 \mathrm{meV})$ assigned to ring-puckering vibrations $v_{33}$, (Table 3 and supplementary information Table 4). The two remaining $3 p$ transitions for the $C_{s}$ conformer are expected at slightly higher energy but with lower intensity. The $7.3 \mathrm{eV}$ feature does not fit into the vibrational progression of the first $3 p\left(C_{s}\right)$ transition. Hence, it is likely that this peak corresponds to the adiabatic transition of the $3 p\left(C_{s}\right)$ transition predicted at 7.296 $\mathrm{eV}$. A single member of a progression involving excitation of a $136.3 \mathrm{~cm}^{-1}(16.9 \mathrm{meV})$ mode is also observed (Table 3 and supplementary information Table 4). On the higher energy side 
of the absorption band, a poorly resolved feature appears at $7.35 \mathrm{eV}$. It could arise from the excitation of the third $3 p\left(C_{s}\right)$ member calculated at $7.381 \mathrm{eV}$. This electronic transition is also accompanied by excitation of the $v_{33}$ mode with $185.5 \mathrm{~cm}^{-1}(23 \mathrm{meV})$ (Table 3 and supplementary information Table 4).

On the low energy side of this absorption band, another structure is observed, which does not fit into the progression associated with the first $3 p\left(C_{s}\right)$ transition. As seen in Table 2, the calculation predicts a $3 p$ transition for the $C_{2}$ conformer at lower energy than the $3 p\left(C_{s}\right)$, but with appreciably lower oscillator strength. The two other $3 \mathrm{p}\left(\mathrm{C}_{2}\right)$ transitions are predicted to have negligible oscillator strength. The maximum of this transition may be estimated from the photoabsorption spectrum (Fig. 3b) at $7.03 \mathrm{eV}$, which fits very well with the theoretical prediction at $7.103 \mathrm{eV}$ for the $3 \mathrm{p}\left(\mathrm{C}_{2}\right)$. We assign the electronic origin of the $3 \mathrm{p}\left(\mathrm{C}_{2}\right)$ transition to the $6.898 \mathrm{eV}$ feature. The progressions identified involve excitation of $183.9 \mathrm{~cm}^{-1}(22.8$ $\mathrm{meV}$ ) vibrational mode, which we assign to the ring-puckering $v_{33}$ modes of this excited states. Associated with the electronic origin is a hot band involving excitation of a $277.5 \mathrm{~cm}^{-1}$ (34.4 meV) mode, which is consistent with the $v_{17}$ wavenumber in the ground state (Table 3 and supplementary information Table 4). Our vibrational assignments for this band are in disagreement with those of Bremner et al. [32]. These authors have looked for a vibrational spacing similar to that observed in the photoelectron spectrum. Indeed, Rydberg states are known to exhibit similar features to the ion to which they converge. We have not followed this procedure in the present case. The computed $\left\langle r^{2}\right\rangle$ (Table 2 ) for the $3 p$ states involved are similar in magnitude to those computed for the $3 \mathrm{~s}$ states for which the vibrational progression are very different from those reported for the ionic ground state (see below). Moreover, the higher resolution of the present data allows us to resolve for the first time fine features on top of the $7.2 \mathrm{eV}$ band (Fig. 2, 3), which were not observed by Bremner et al. [34].

\subsubsection{The $3 \mathrm{~d}$ terms of the series converging to the ionic ground electronic state} Similar to the $3 \mathrm{~s}$ and $3 \mathrm{p}$ series, excitation of the first $3 \mathrm{~d}$ members is predicted to occur at a noticeably lower energy for the $\mathrm{C}_{2}$ conformer than for the $\mathrm{C}_{2}$. Hence, Table 2 shows that the first $3 \mathrm{~d}\left(\mathrm{C}_{2}\right)$ state should be expected on the high-energy side of the $3 p$ absorption band. As seen in Fig. 3b, a broad feature is observed at $7.483 \mathrm{eV}$, not well resolved from the underlying background but which agrees with the theoretical value of $7.474 \mathrm{eV}$ for the excitation of the $3 \mathrm{~d}\left(\mathrm{C}_{2}\right)$ state. The spectral region extending from $7.40 \mathrm{eV}$ to $8.15 \mathrm{eV}$ is predicted to contain the $3 \mathrm{~d}$ transitions for both conformers, which are computed to account for most of the 
oscillator strength (Table 2). An enlargement of the spectrum shows a congested spectral region with quite sharp features. Two intense features are observed at $7.730 \mathrm{eV}$ and $7.813 \mathrm{eV}$ (Fig. 3b). These values match the predicted transition energies to two $3 d\left(C_{2}\right)$ states at 7.715 $\mathrm{eV}$ and $7.754 \mathrm{eV}$. Following Bremner et al. [32], in searching for vibrational progression associated with these origins, it appeared that the shapes of these bands matched the first band of the photoelectron spectrum. The difference with the previous Rydberg states lies in greater $\left\langle r^{2}\right\rangle$ values, as seen at Table 2. This more diffuse character explains the resemblance of these states with the ionic core. The vibrational assignments are summarized in Table 3 with also supplementary information Table 5.

A feature located at $7.749 \mathrm{eV}$ and poorly resolved from the $7.730 \mathrm{eV}$ peak is assigned to the lowest energy $3 \mathrm{~d}\left(\mathrm{C}_{\mathrm{s}}\right)$ transition, on the basis of its computed value of $7.724 \mathrm{eV}$. The remaining $3 \mathrm{~d}\left(\mathrm{C}_{\mathrm{s}}\right)$ excitations are predicted to be grouped around $8 \mathrm{eV}$ but dominated by an intense excitation. We tentatively assign this excitation to the $7.867 \mathrm{eV}$ feature, appearing as a shoulder on the $7.973 \mathrm{eV}$ peak.

\subsubsection{Higher excited states}

The spectral region spanning from 8.2 to $10.6 \mathrm{eV}$ is shown in Fig. 4. Table 4 shows our assignments of features attributable to Rydberg series converging to the first three ionisation limits. We report a single member of the ns series converging to the first ionisation limit for both conformers. The computed oscillator strengths for higher members of the progression are in every case too low to be observed (see Table 2). This result is in agreement with Bremner et al. [32]. Interestingly, the calculation predicts more intense np members $(\mathrm{n}>3)$ for the $\mathrm{C}_{\mathrm{s}}$ isomer. Our assignments follow from that and we report members up to $\mathrm{n}=5$ for the $n p$ series of the $C_{s}$ isomers converging to the first ionic limit. The $n=4$ members have $\delta$ values consistent with $\mathrm{np}$ excitations. We tentatively assign $5 \mathrm{p}$ members on the basis of the calculations, despite quantum defect values not being in perfect agreement with this assignment. Bremner et al. [32] report a single $5 \mathrm{p}$ member at $8.89 \mathrm{eV}$. We also report this member at $8.888 \mathrm{eV}$ along with another one at 8.939 .

For the $C_{2}$ isomer, nd series have been assigned up to $n=9$, with consistent quantum defects. For the $\mathrm{C}_{\mathrm{s}}$ isomer, nd series are reported up to $\mathrm{n}=7$. These assignments, although at variance 
with the report of Bremner et al. [32] of two 3d series, are guided by the theoretical calculations.

Series converging to the second ionisation limit are reported for the $\mathrm{C}_{2}$ isomer only. In agreement with Bremner et al. [32] and guided by the present calculations, we place a 3s series at $\sim 8.3 \mathrm{eV}$. Moreover, we report two $3 \mathrm{p}$ series and a single $3 \mathrm{~d}$ series, for the first time. The calculation predicts a $3 \mathrm{~s}\left(\mathrm{C}_{2}\right)$ and a $3 \mathrm{p}\left(\mathrm{C}_{\mathrm{s}}\right)$ converging to the third ionisation limit with noticeable oscillator strength. These members have been respectively assigned to the features at $8.965 \mathrm{eV}$ and $9.037 \mathrm{eV}$ with $\delta$ values of 0.870 and 0.655 supporting these assignments.

\subsection{Ionic states}

The He(I) photoelectron spectrum of THF is shown at Fig. 5(a). The ionic states have been calculated using the Outer Valence Green's Function (OVGF)/aug-ccp VDZ method. Table 5 shows the results for the $\mathrm{C}_{\mathrm{s}}$ and $\mathrm{C}_{2}$ conformers of the ground electronic state that were considered in this work, and compared with previous theoretical and experimental data. Our experimental results are in good agreement with those of Yang et al. [25], Kimura et al. [48] and Yamauchi et al. [49] where they overlap. Nevertheless, this work reports experimental ionisation energies with higher precision and the highest level of theoretical description. The ordering of the OVGF ionisation energies is in agreement with those of Yang et al. [25] except for the $\mathrm{C}_{\mathrm{s}}$ conformer for which several discrepancies are found.

We have calculated the geometries of the ionic ground states at the UMP2/aug-cc-pVDZ level. It appears that, starting from the $\mathrm{C}_{2}$ geometry of the ground electronic state, the $\tilde{X}^{2} \mathrm{~B}$ state remains $\mathrm{C}_{2}$ in nature with all its vibrational frequencies real (see supplementary information table 6). In contrast when the corresponding doublet is considered for the $\mathrm{C}_{\mathrm{s}}$ conformer $\left(\tilde{X}^{2} \mathrm{~A}^{\prime}\right)$, the calculation converges towards the $\mathrm{C}_{2 \mathrm{v}}$ geometry. The computed vibrational frequencies for $C_{2 v}$ give one imaginary $A_{2}$ mode $\left(v_{17}\right)$ of $188 \mathrm{~cm}^{-1}(23.3 \mathrm{meV})$, which breaks the symmetry towards $\mathrm{C}_{2}$. Hence, the topology of the ionic ground state potential energy surface is the following: two equivalent $C_{2}$ geometries separated by a $C_{2 v}$ saddle point giving a barrier of $1093.1 \mathrm{~cm}^{-1}$ (calculated with ZPE correction). The geometrical parameters for the $\mathrm{C}_{2}$ and $\mathrm{C}_{2 \mathrm{v}}$ conformers of the positive ion are given at supplementary information table 1. 
The first band of the photoelectron spectrum, shown at figure 5(b), extends from 9.3 to 10.3 $\mathrm{eV}$. It appears to be composed (with the present $50 \mathrm{meV}$ resolution) of a first feature peaking at $9.433 \mathrm{eV}$ not completely resolved from a broader one on its high energy side. This band contains at least three features at $9.586 \mathrm{eV}, 9.66 \mathrm{eV}$ and $9.718 \mathrm{eV}$, which were not reported by Yang et al. [25]. The adiabatic transition is assigned to $9.433 \mathrm{eV}$. We assign the $9.586 \mathrm{eV}$ feature to vibrational excitation involving one quantum of mode $v_{26}$ with $1234 \mathrm{~cm}^{-1}$, which agrees well with the computed value of $1243.3 \mathrm{~cm}^{-1}(154 \mathrm{meV})$ for the $\mathrm{C}_{\mathrm{s}}$ geometry. This mode also is found combined with $v_{32}$ and $v_{11}$ at $596.8(74 \mathrm{meV})$ and $1064.7 \mathrm{~cm}^{-1}(132 \mathrm{meV})$ at $9.66 \mathrm{eV}$ and $9.718 \mathrm{eV}$. These wavenumbers are consistent with excitations of reported values for the neutral ground state. Values are gathered in table 3 and supplementary information table 7.

According to the theoretical prediction, the ionisation energy of the $\mathrm{C}_{\mathrm{s}}$ isomer is lower than that of the $\mathrm{C}_{2}$ by $34 \mathrm{meV}$. We cannot resolve at the present experimental resolution two transitions so close in energy. Hence it is very likely that the two electronic origins for the $\mathrm{C}_{2}$ and $\mathrm{C}_{\mathrm{s}}$ isomers are superimposed and both contribute to the $9.433 \mathrm{eV}$ peak.

The energy resolution of the electron momentum spectroscopy of Yang et al. [25] is around 1 $\mathrm{eV}$ [50]. This resolution is too poor to allow Yang et al. [25] to resolve the vibrational excitations associated with excitation of the ground ionic state we report. A fortiori, they cannot separate the contribution from the two major conformers of THF, which appear undistinguishable at the present $50 \mathrm{meV}$ resolution.

\section{Conclusions}

This paper revisits the electronic spectroscopy of THF in the light of the first ab initio calculations ever performed to our knowledge on the excited states of the neutral molecule.

On the basis of the excellent agreement between the calculations and the measurements, we report that the experimental spectrum is composite and contains electronic excitations from both $\mathrm{C}_{\mathrm{s}}$ and $\mathrm{C}_{2}$ conformers of THF. Hence, this provides a solution to previous discrepancies in the literature concerning the nature of the lowest energy transitions for the molecule. The electronic spectrum has been re-examined up to $10.3 \mathrm{eV}$ and new vibrational progression reported for the $3 p$ and $3 d$ Rydberg states. Higher members of Rydberg series are re-assigned in the light of the calculations. 
The lowest energy part of the photoelectron spectrum is reported and an accurate value for the lowest adiabatic ionisation energy is reported. Calculations predict adiabatic transition to the ionic ground state to be separated by $34 \mathrm{meV}$ for the two $\mathrm{C}_{2}$ and $\mathrm{C}_{\mathrm{s}}$ lowest energy conformers of the THF such that the present experimental resolution cannot resolve the separate contribution of the two conformers. Yang et al. [25] have reported experimental orbital momentum distribution for the HOMO of THF and compared these data to simulated distribution for the $\mathrm{C}_{2}$ and $\mathrm{C}_{\mathrm{s}}$ isomers. Since better agreement of the simulated distribution was obtained for the $\mathrm{C}_{\mathrm{s}}$ isomer, the authors concluded the most stable conformer of THF to be the $\mathrm{C}_{\mathrm{s}}$ one. Our work seems to indicate that both conformers coexist in the gas phase at room temperature and might be observed. Consequently, we question the conclusions of Yang et al. [25] about the reliability of their methodology to provide a new diagnostic for the most populated conformer of THF in the gas phase at room temperature.

\section{Acknowledgments}

We wish to thank the ISA at Aarhus,Denmark for access to the Astrid synchrotron under the EU FP6 programme IA-SFS contract number R113-CT-2004-506008. We also acknowledge support from the ESF EIPAM and ESF COST Action P9 (RADAM). We thank Pr Jose A. Sordo for providing details on his calculations. ARM and BPM acknowledge the support of the Ministry of Science of Republic of Serbia under Project No. 141011. The "PhLAM" is "Unité Mixte de Recherche du CNRS". The "Centre d'Études et de Recherches Lasers et Applications" (CERLA, FR CNRS 2416) is supported by the "Ministère chargé de la Recherche", the "Région Nord/Pas-de-Calais" and the "Fonds Européen de Développement Économique des Régions" (FEDER). The computations were carried out at the CRI (Centre de Ressources Informatiques), on the IBM computer which is supported by the "Programme de Calcul Intensif et Parallèle" of the "Ministère chargé de la Recherche", the "Région Nord/Pas-de-Calais" and the FEDER. NJM wishes to thank the UK EPSRC for financial support. PLV acknowledges the honorary research fellow position at University College London, the visiting fellow position at CEMOS, The Open University, UK, and together with M-J H-F the financial support from the Portuguese-Belgian joint collaboration. The Patrimoine of the University of Liège, the Fonds de la Recherche Scientifique (FRS-FNRS) and the Fonds de la Recherche Fondamentale Collective of Belgium have supported this research. M-J H-F wishes to acknowledge the Fonds de la Recherche Scientifique for 
position. PLV and NJM acknowledge the support from the British Council for the PortugueseEnglish joint collaboration.

\section{References}

1. L. Sanche, Eur. J. Phys. D 35, 367 (2005)

2. B. Boudaiffa, P. Cloutier, D. Hunting, M. A. Huels, L. Sanche, Science 287, 1658 (2000)

3. C. von Sonntag, in The Chemical Basis for Radiation Biology, (Francis, London, 1987)

4. M. Lepage, S. Letarte, M. Michaud, F. Motte-Tollet, M.-J. Hubin-Franskin, D. Roy, L. Sanche, J. Chem. Phys. 109, 5980 (1998)

5. D. Antic, L. Parenteau, M. Lepage, L. Sanche, J. Phys. Chem. B 103, 6611 (1999)

6. D. Antic, L. Parenteau, L. Sanche, J. Phys. Chem. B 104, 4711 (2000)

7. S.-P. Breton, M. Michaud, C. Jäggle, P. Swiderek, L. Sanche, J. Chem. Phys. 121, 11240 (2004)

8. A. R. Milosavljevic, A. Giuliani, D. Sevic, M.-J. Hubin-Franskin, B. P. Marinkovic, Eur. J. Phys. D 35, 411 (2005)

9. Zecca, C. Perazzolli, M. J. Brunger, J. Phys. B 38, 2079 (2005)

10. P. Mozejko, L. Sanche, Radiat. Phys. Chem. 73, 77 (2005)

11. D. Bouchiha, J. D. Gorfinkiel, L. G. Caron, L. Sanche, J. Phys. B 39, 975 (2006)

12. C. S. Trevisan, A. E. Orel, T. N. Rescigno, J. Phys. B 39, L255 (2006)

13. C. Winstead, V. McKoy, J. Chem. Phys. 125, 074302 (2006)

14. Y. S. Park, H. Cho, L. Parenteau, A. D. Bass, L. Sanche, J. Chem. Phys. 125, 074714 (2006)

15. P. Sulzer, S. Ptasinska, F. Zappa, B. Mielewska, A. R. Milosavljevic, P. Scheier, T. Mark, J. Chem. Phys. 125, 044304 (2006)

16. A. Wu, D. Cremer, Int. J. Mol. Sci. 4, 158 (2003)

17. W. Saenger, in Principle of Nucleic Acid Structure, (Springer-Verlag, New York, 1984)

18. G. G. Engerholm, A. C. Luntz, W. D. Gwinn, D. O. Harris, J. Chem. Phys. 50, 2446 (1969)

19. R. Meyer, J. C. Lopez, J. L. Alonso, S. Melandri, P. G. Favero, W. Caminati, J. Chem. Phys. 111, 7871 (1999)

20. A. H. Mamleev, L. N. Gunderova, R. V. Galley, J. Struct. Chem. 42, 365 (2001)

21. D. G. Melnik, S. Gopalakrishnan, T. A. Miller, J. Chem. Phys. 118, 3589 (2003)

22. B. Cadioli, E. Gallinella, C. Coulombeau, H. Jobic, G. Berthier, J. Phys. Chem. 97, 7844 (1993)

23. S. J. Han, Y. K. Kang, J. Mol. Struct. : THEOCHEM 369, 157 (1996)

24. V. M. Rayón, J. A. Sordo, J. Chem. Phys. 122, 204303 (2005)

25. T. Yang, G. Su, C. Ning, J. Deng, F. Wang, S. Zhang, X. Ren, Y. Huang, J. Chem. Phys. 111, 4927 (2007)

26. L. W. Pickett, N. J. Hoeflich, T. C. Liu, J. Am. Chem. Soc. 73 (1951) 4865

27. G. J. Hernandez, J. Chem. Phys. 38, 2233 (1963)

28. R. Davidson, J. Høg, P. A. Warsop, J. A. B. Whiteside, J. Chem. Soc. Faraday II 68, 1652 (1972)

29. M. B. Robin, Higher Excited States of Polyatomic Molecules Volume II, (Academic Press, New York and London, 1974)

30. W.-C. Tam, C. E. Brion, J. Electron Spectrosc. Relat. Phenom. 3, 263 (1974) 
31. J. Doucet, P. Sauvegeau, C. Sandorfy, Chem. Phys. Lett., 19, 316 (1973)

32. L. J. Bremner, M. G. Curtis, I. C. Walker, J. Chem. Soc. Faraday Trans. 87, 1049 (1991)

33. A. Giuliani, J. Delwiche, S. V. Hoffmann, P. Limão-Vieira, N. J. Mason, M.-J. Hubin-Franskin, J. Chem. Phys. 119, 3670 (2003)

34. J. Delwiche, P. Natalis, J. Momigny, J. E. Collin, J. Electron Spec. Relat. Phenom. 1, 219 (1972)

35. D. R. Lide (Editor), in Handbook of Chemistry and Physics (CRC Press, New York,1992)

36. J. H. D. Eland, in Photoelectron spectroscopy (Butterworth \& Co Ltd., London, 1984)

37. A. R. Milosavljević, S. Madžunkov, D. Šević, I. Čadež, B. P. Marinković, J. Phys. B: At. Mol. Opt. Phys. 39, 609 (2006)

38. C. Hampel, K. Peterson, H.-J. Werner, Chem. Phys. Lett. 190, 1 (1992).

39. MOLPRO, a package of ab initio programmes designed by H.-J. Werner and P. J. Knowles, version 2006.1, R. D. Amos, A. Bernhardsson, A. Berning, P. Celani, D. L. Cooper, M. J. O. Deegan, A. J. Dobbyn, F. Eckert, C. Hampel, G. Hetzer, P. J. Knowles, T. Korona, R. Lindh, A. W. Lloyd, S. J. McNicholas, F. R. Manby, W. Meyer, M. E. Mura, A. Nicklass, P. Palmieri, R. Pitzer, G. Rauhut, M. Schütz, U. Schumann, H. Stoll, A. J. Stone, R. Tarroni, T. Thorsteinsson, H.-J. Werner.

40. K. Kaufmann, W. Baumeister, M. Jungen, J. Phys. B 22, 2223 (1989)

41. J. V. Ortiz, V. G. Zakrzewski, O. Dolgounircheva, in Conceptual Perspectives in Quantum Chemistry, Edited by J.-L. Calais and E. Kryachko (Kluwer Academic, 1997)

42. J. V. Ortiz, J. Chem. Phys. 89, 6348 (1988)

43. M. J. Frisch, G. W. Trucks, H. B. Schlegel, G. E. Scuseria, M. A. Robb, J. R. Cheeseman, J. A. Montgomery Jr, T. Vreven, K. N. Kudin, J. C. Burant, J. M. Millam, S. S. Iyengar, J. Tomasi, V. Barone, B. Mennucci, M. Cossi, G. Scalmani, N. Rega, G. A. Petersson, H. Nakatsuji, M. Hada, M. Ehara, K. Toyota, R. Fukuda, J. Hasegawa, M. Ishida, T. Nakajima, Y. Honda, O. Kitao, H. Nakai, M. Klene, X. Li, J. E. Knox, H. P. Hratchian, J. B. Cross, V. Bakken, C. Adamo, J. Jaramillo, R. Gomperts, R. E. Stratmann, O. Yazyev, A. J. Austin, R. Cammi, C. Pomelli, J. W. Ochterski, P. Y. Ayala, K. Morokuma, G. A. Voth, P. Salvador, J. J. Dannenberg, V. G. Zakrzewski, S. Dapprich, A. D. Daniels, M. C. Strain, O. Farkas, K. D. Malick, A. D. Rabuck, K. Raghavachari, J. B. Foresman, J. V Ortiz, Q. Cui, A. G. Baboul, S. Clifford, J. Cioslowski, B. B. Stefanov, G. Liu, A. Liashenko, P. Piskorz, I.

Komaromi, R. L. Martin, D. J. Fox, T. Keith, M. A. Al-Laham, C. Y. Peng, A. Nanayakkara, M. Challacombe, P. M. W. Gill, B. Johnson, W. Chen, M. W. Wong, C. Gonzalez, J. A. Pople, Gaussian 03, Revision D.01. Gaussian, Inc., Wallingford CT, (2004)

44. P. Luger, J. Buschmann, Angew. Chem. 95, 423 (1983)

45. W. I. F. David, R. M. Ibberson, Acta Crystallogr., Sect. C 48, 301 (1992)

46. E. Gallinella, B. Cadioli, J.-P. Flament, G. Berthier, J. Mol. Struct. (THEOCHEM) 315, 137 (1994)

47. Y. Morino, K. Kuchistu, J. Chem. Phys. 20,1809 (1952)

48. K. Kimura, S. Katsuwata, Y. Achiba, T. Yamazaki, S. Iwata, in Handbook of HeI Photoelectron Spectra of fundamental Organic Molecules (Halsted Press, New York, 1981)

49. M. Yamauchi, H. Yamakado, K. Ohno, J. Phys. Chem. A 101, 6184 (1997)

50. X. G. Ren, C. G. Ning, J. K. Deng, S. F. Zhang, G. L. Su, F. Huang, G. Q. Li, Rev. 
Sci. Instrum. 76, 063103 (2005)

$-17-$ 


\section{Figure Captions}

Figure 1. (a) Structure of THF with atom numbering. (b) Pseudorotation of THF. Half of the cycle of the pseudorotation angle $\left(\phi=0\right.$ to $\left.180^{\circ}\right)$ is shown. Picture adapted from references 17 and 25.

Figure 2. High-resolution photoabsorption spectrum (a) and electron energy loss spectrum (b) of THF recorded at $100 \mathrm{eV}$ and $10^{\circ}$ scattering angle.

Figure 3. High-resolution photoabsorption spectrum of THF (full lines) and theoretical calculations (vertical lines). The circles refer to the $C_{2}$ geometry and the triangles to the $C_{s}$ one. (a). Detail of the $3 \mathrm{~s}$ transition region and the associated vibrational progressions. (b) Detail of the $3 p$ and $3 d$ transitions and associated vibrational progressions. The trace of the first band of the photoelectron spectrum is shown in dots.

Figure 4. High-resolution photoabsorption spectrum of THF in the 8.2-10.6 eV showing Rydberg states and vibrational progressions.

Figure 5. He(I) photoelectron spectrum of THF (a) in the 8-16 eV energy region, (b) detail of the first band in the 9.1-10.6 eV energy region.

\section{Table Captions}

Table 1. Pseudorotation angle (in degree), symmetry and description of the potential energy surface minima for THF as determined from experiments and theoretical calculations.

Table 2. Experimental vertical excitation energies $(\mathrm{eV})$ compared to theoretical transition energies $(\mathrm{eV})$ and oscillator strength calculated for the $\mathrm{C}_{2}$ and $\mathrm{C}_{\mathrm{s}}$ conformers of THF.

Table 3. Comparison of the vibrational progressions found for THF for the neutral electronic ground states, the neutral electronic excited states and the ionic electronic ground state. Wavenumber are those of table $2\left(\right.$ in $\left.^{-1}\right)$.

Table 4. Rydberg series analysis. Energies in eV. Quantum defects are calculated according to the Rydberg formula, see text.

Table 5. Experimental ionisation energies and band assignments for THF. 
Table 1. Pseudorotation angle (in degree), symmetry and description of the potential energy surface minima for THF as determined from experiments and theoretical calculations.

\begin{tabular}{|c|c|c|c|c|c|c|}
\hline \multirow[b]{2}{*}{ Experiments } & \multicolumn{3}{|c|}{ Global minimum } & \multicolumn{3}{|c|}{ Local minimum } \\
\hline & $\phi$ & Conform. & Symmetry & $\phi$ & Conform. & Symmetry \\
\hline \multicolumn{7}{|l|}{$\mathrm{MW}^{\mathrm{a}}$} \\
\hline Engerholm et al. [18] & 56 & $\sim{ }_{5} \mathrm{E}$ & $\mathrm{C}_{1}$ & & & \\
\hline Meyer et al. [19] & 52.5 & $\sim{ }_{5} \mathrm{E}$ & $\mathrm{C}_{1}$ & & & \\
\hline Mamleev et al. [20] & 90 & 4 & $\mathrm{C}_{2}$ & 0,180 & ${ }_{1} \mathrm{E},{ }^{1} \mathrm{E}$ & $\mathrm{C}_{\mathrm{s}}$ \\
\hline Melnik et al. [21] & 90 & $\check{4}^{\prime}$ & $\mathrm{C}_{2}$ & 0,180 & ${ }_{1} \mathrm{E},{ }^{1} \mathrm{E}$ & $\mathrm{C}_{\mathrm{s}}$ \\
\hline \multicolumn{7}{|l|}{ EMS $^{\mathrm{b}}$} \\
\hline Yang et al. [25] & & ${ }_{1} \mathrm{E}$ & $\mathrm{C}_{\mathrm{s}}$ & & & \\
\hline \multicolumn{7}{|l|}{ Theory } \\
\hline This Work & 90 & 4 & $\mathrm{C}_{2}$ & 0,180 & ${ }_{1} \mathrm{E},{ }^{1} \mathrm{E}$ & $\mathrm{C}_{\mathrm{s}}$ \\
\hline Cadioli et al. [22] & 90 & $\breve{4}^{\prime} 1$ & $\mathrm{C}_{2}$ & 0,180 & ${ }_{1} \mathrm{E},{ }^{1} \mathrm{E}$ & $\mathrm{C}_{\mathrm{s}}$ \\
\hline Han and Kang [23] & 90 & $\check{4}^{\prime}$ & $\mathrm{C}_{2}$ & 0,180 & ${ }_{1} \mathrm{E},{ }^{1} \mathrm{E}$ & $\mathrm{C}_{\mathrm{s}}$ \\
\hline Wu and Cremer [16] & 90 & $\breve{4}$ & $\mathrm{C}_{2}$ & & & \\
\hline Rayón and Sordo [24] & 0 & ${ }_{1} \mathrm{E}$ & $\mathrm{C}_{\mathrm{s}}$ & 90 & $\breve{4}^{\prime}$ & $\mathrm{C}_{2}$ \\
\hline
\end{tabular}

${ }^{\mathrm{a}}$ Microwave spectroscopy. ${ }^{\mathrm{b}}$ Electron momentum spectroscopy. 
Table 2. Experimental vertical excitation energies $(\mathrm{eV})$ compared to theoretical transition energies $(\mathrm{eV})$ and oscillator strength calculated for the $\mathrm{C}_{2}$ and $\mathrm{C}_{\mathrm{s}}$ conformers of THF.

\begin{tabular}{|c|c|c|c|c|c|c|c|}
\hline $\bar{E}$ & Conformation & Symmetry & $\begin{array}{c}\mathrm{f} \\
\left(\mathrm{x} 10^{-2}\right)\end{array}$ & $<\mathrm{r}^{2}>$ & $\mathrm{HOMO}^{\mathrm{c}}$ & SHOMO $^{d}$ HOMO-2 ${ }^{\mathrm{e}}$ & Exp. \\
\hline 6.357 & $\mathrm{C}_{2}$ & $\mathrm{~B}$ & 0.6 & 111 & $3 \mathrm{~s}$ & & $6.221^{\mathrm{a}}$ \\
\hline 6.608 & $\mathrm{C}_{\mathrm{s}}$ & $A^{\prime}$ & 1.3 & 108 & $3 \mathrm{~s}$ & & $6.353^{a}$ \\
\hline 6.889 & $\mathrm{C}_{2}$ & A & 0.04 & 126 & $3 p$ & & - \\
\hline 7.025 & $\mathrm{C}_{2}$ & $\mathrm{~A}$ & 0.02 & 140 & $3 p$ & & - \\
\hline 7.103 & $\mathrm{C}_{2}$ & B & 0.2 & 138 & $3 p$ & & $6.898^{a}$ \\
\hline 7.154 & $\mathrm{C}_{\mathrm{s}}$ & $\mathrm{A}^{\prime}$ & 4.7 & 127 & $3 p$ & & $7.142^{\mathrm{a}}$ \\
\hline 7.296 & $\mathrm{C}_{\mathrm{s}}$ & $A^{\prime \prime}$ & 0.3 & 140 & $3 p$ & & $7.300^{\mathrm{a}}$ \\
\hline 7.381 & $\mathrm{C}_{\mathrm{s}}$ & $\mathrm{A}^{\prime}$ & 0.7 & 144 & $3 p$ & & $7.350^{\mathrm{v}}$ \\
\hline 7.474 & $\mathrm{C}_{2}$ & $\mathrm{~B}$ & 0.9 & 143 & $3 d$ & & $7.483^{\mathrm{v}}$ \\
\hline 7.713 & $\mathrm{C}_{2}$ & A & 0.002 & 170 & $3 d$ & & - \\
\hline 7.715 & $\mathrm{C}_{2}$ & $\mathrm{~B}$ & 1.67 & 184 & $3 d$ & & $7.730^{\mathrm{a}}$ \\
\hline 7.724 & $\mathrm{C}_{\mathrm{s}}$ & $\mathrm{A}^{\prime}$ & 0.37 & 143 & $3 d$ & & $7.749^{\mathrm{a}}$ \\
\hline 7.754 & $\mathrm{C}_{2}$ & $\mathrm{~B}$ & 2.07 & 179 & $3 d$ & & $7.813^{\mathrm{a}}$ \\
\hline 7.859 & $\mathrm{C}_{2}$ & $\mathrm{~A}$ & 0.06 & 198 & $3 d$ & & - \\
\hline 7.978 & $\mathrm{C}_{\mathrm{s}}$ & $\mathrm{A}^{\prime \prime}$ & 0.28 & 169 & $3 d$ & & - \\
\hline 7.985 & $\mathrm{C}_{\mathrm{s}}$ & $A^{\prime}$ & 1.5 & 183 & $3 d$ & & $7.867^{\mathrm{a}}$ \\
\hline 7.988 & $\mathrm{C}_{2}$ & $\mathrm{~B}$ & 0.05 & 293 & $4 s$ & & - \\
\hline 8.017 & $\mathrm{C}_{\mathrm{s}}$ & $\mathrm{A}^{\prime \prime}$ & 0.72 & 180 & $3 d$ & & - \\
\hline 8.103 & $\mathrm{C}_{\mathrm{s}}$ & $\mathrm{A}^{\prime}$ & 0.02 & 196 & $3 d$ & & - \\
\hline 8.144 & $\mathrm{C}_{2}$ & A & 0.02 & 372 & $4 p$ & & - \\
\hline 8.188 & $\mathrm{C}_{2}$ & $\mathrm{~B}$ & 0.01 & 369 & $4 p$ & & - \\
\hline 8.194 & $\mathrm{C}_{2}$ & $\mathrm{~A}$ & 0.00003 & 405 & $4 s$ & & \\
\hline 8.249 & $\mathrm{C}_{\mathrm{s}}$ & $A^{\prime}$ & 0.18 & 285 & $4 s$ & & \\
\hline 8.288 & $\mathrm{C}_{2}$ & A & 1.12 & 120 & & $3 \mathrm{~s}$ & $8.3^{\mathrm{v}}$ \\
\hline 8.335 & $\mathrm{C}_{2}$ & $\mathrm{~B}$ & 0.17 & 454 & $4 d$ & & $8.515^{\mathrm{v}}$ \\
\hline 8.405 & $\mathrm{C}_{\mathrm{s}}$ & $\mathrm{A}^{\prime}$ & 0.97 & 369 & $4 p$ & & $8.37^{\mathrm{v}}$ \\
\hline 8.422 & $\mathrm{C}_{2}$ & $\mathrm{~B}$ & 0.23 & 558 & $4 d$ & & $8.533^{\mathrm{v}}$ \\
\hline 8.439 & $\mathrm{C}_{2}$ & $\mathrm{~A}$ & 0.002 & 530 & $4 d$ & & \\
\hline 8.451 & $\mathrm{C}_{\mathrm{s}}$ & $\mathrm{A}^{\prime \prime}$ & 0.095 & 393 & $4 p$ & & \\
\hline 8.457 & $\mathrm{C}_{2}$ & $\mathrm{~B}$ & 1.13 & 558 & $4 d$ & & $8.557^{\mathrm{v}}$ \\
\hline 8.460 & $\mathrm{C}_{\mathrm{s}}$ & $\mathrm{A}^{\prime}$ & 0.61 & 345 & $4 p$ & & $8.4^{\mathrm{v}}$ \\
\hline 8.494 & $\mathrm{C}_{\mathrm{s}}$ & $\mathrm{A}^{\prime}$ & 0.16 & 170 & & $3 \mathrm{~s}$ & \\
\hline 8.496 & $\mathrm{C}_{2}$ & A & 0.003 & 598 & $4 d$ & & \\
\hline 8.545 & $\mathrm{C}_{2}$ & $\mathrm{~B}$ & 0.038 & 770 & $5 s$ & & \\
\hline 8.584 & $\mathrm{C}_{\mathrm{s}}$ & & 0.007 & 443 & $4 d$ & & \\
\hline 8.615 & $\mathrm{C}_{2}$ & A & 0.0008 & 975 & $5 p$ & & \\
\hline 8.623 & $\mathrm{C}_{2}$ & B & 0.0033 & 907 & $5 p$ & & \\
\hline 8.635 & $\mathrm{C}_{2}$ & $\mathrm{~A}$ & 0.0003 & 1019 & $5 p$ & & \\
\hline
\end{tabular}




\begin{tabular}{|c|c|c|c|c|c|c|c|c|}
\hline 8.684 & $\mathrm{C}_{\mathrm{s}}$ & $\mathrm{A}^{\prime \prime}$ & 0.0012 & 140 & & $3 s$ & & \\
\hline 8.693 & $\mathrm{C}_{\mathrm{s}}$ & $\mathrm{A}^{\prime}$ & 0.40 & 550 & $4 d$ & & & $8.652^{\mathrm{v}}$ \\
\hline 8.700 & $\mathrm{C}_{\mathrm{s}}$ & $\mathrm{A}^{\prime \prime}$ & 0.12 & 527 & $4 d$ & & & $8.695^{\mathrm{v}}$ \\
\hline 8.715 & $\mathrm{C}_{2}$ & $\mathrm{~B}$ & 0.03 & 1030 & $5 d$ & & & \\
\hline 8.720 & $\mathrm{C}_{\mathrm{s}}$ & $\mathrm{A}^{\prime \prime}$ & 0.19 & 555 & $4 d$ & & & $8.719^{\mathrm{v}}$ \\
\hline 8.751 & $\mathrm{C}_{\mathrm{s}}$ & $\mathrm{A}^{\prime}$ & 0.005 & 591 & $4 d$ & & & \\
\hline 8.760 & $\mathrm{C}_{2}$ & $\mathrm{~B}$ & 0.055 & 1244 & $5 d$ & & & \\
\hline 8.792 & $\mathrm{C}_{2}$ & B & 0.6 & 180 & & $3 p$ & & $8.793^{\mathrm{v}}$ \\
\hline 8.800 & $\mathrm{C}_{2}$ & A & 0.006 & 839 & $5 d$ & & & \\
\hline 8.808 & $\mathrm{C}_{\mathrm{s}}$ & $A^{\prime}$ & 0.063 & 752 & $5 s$ & & & \\
\hline 8.824 & $\mathrm{C}_{2}$ & $\mathrm{~B}$ & 1.11 & 887 & $5 d$ & & & $8.875^{\mathrm{v}}$ \\
\hline 8.842 & $\mathrm{C}_{2}$ & $\mathrm{~B}$ & 0.0265 & 1546 & $6 s$ & & & \\
\hline 8.850 & $\mathrm{C}_{2}$ & A & 0.0092 & 835 & $5 d$ & & & \\
\hline 8.857 & $\mathrm{C}_{2}$ & A & 0.00015 & 1713 & $6 p$ & & & \\
\hline 8.861 & $\mathrm{C}_{2}$ & A & 0.0017 & 1560 & $6 p$ & & & \\
\hline 8.872 & $\mathrm{C}_{\mathrm{s}}$ & $\mathrm{A}^{\prime}$ & 0.322 & 937 & $5 p$ & & & $8.888^{\mathrm{v}}$ \\
\hline 8.881 & $\mathrm{C}_{2}$ & $\mathrm{~B}$ & 0.239 & 1210 & $6 p$ & & & \\
\hline 8.889 & $\mathrm{C}_{2}$ & B & 0.477 & 607 & & $3 p$ & & $8.844^{\mathrm{v}}$ \\
\hline 8.899 & $\mathrm{C}_{\mathrm{s}}$ & $A^{\prime}$ & 0.206 & 985 & $5 p$ & & & $8.939^{\mathrm{v}}$ \\
\hline 8.901 & $\mathrm{C}_{\mathrm{s}}$ & $\mathrm{A}^{\prime \prime}$ & 0.040 & 1013 & $5 p$ & & & \\
\hline 8.928 & $\mathrm{C}_{2}$ & A & 0.028 & 281 & $\sigma *$ & & & \\
\hline 8.934 & $\mathrm{C}_{2}$ & A & 0.004 & 377 & & $3 p$ & & \\
\hline 8.965 & $\mathrm{C}_{\mathrm{s}}$ & $A^{\prime}$ & 0.003 & 1032 & $5 d$ & & & \\
\hline 8.966 & $\mathrm{C}_{2}$ & A & 0.308 & 198 & & & $3 s$ & $8.965^{\mathrm{v}}$ \\
\hline 9.014 & $\mathrm{C}_{\mathrm{s}}$ & $\mathrm{A}^{\prime}$ & 0.738 & 519 & $5 d$ & & & $9.024^{\mathrm{v}}$ \\
\hline 9.039 & $\mathrm{C}_{\mathrm{s}}$ & $\mathrm{A}^{\prime \prime}$ & 2.43 & 172 & & & $3 p$ & $9.137^{\mathrm{v}}$ \\
\hline 9.040 & $\mathrm{C}_{\mathrm{s}}$ & $A^{\prime}$ & 0.103 & 775 & $5 d$ & & & \\
\hline 9.064 & $\mathrm{C}_{\mathrm{s}}$ & $\mathrm{A}^{\prime \prime}$ & 0.020 & 877 & $5 d$ & & & \\
\hline 9.081 & $\mathrm{C}_{\mathrm{s}}$ & $\mathrm{A}^{\prime \prime}$ & 0.474 & 820 & $5 d$ & & & $8.991^{\mathrm{v}}$ \\
\hline
\end{tabular}

${ }^{\mathrm{a}}$ stands for adiabatic and ${ }^{\mathrm{v}}$ stands for vertical.

${ }^{\mathrm{c}} \mathrm{HOMO}$ : $9 \mathrm{~b}$ for $\mathrm{C}_{2}$ and 12a' for $\mathrm{C}_{\mathrm{s}}$. ${ }^{\mathrm{d}}$ SHOMO: 11a for $\mathrm{C}_{2}$ and 8a" for $\mathrm{C}_{\mathrm{s}} .{ }^{\mathrm{e}} \mathrm{HOMO}-2$ : 10a for $\mathrm{C}_{2}$ and 11a' for $\mathrm{C}_{\mathrm{s}}$. 
Table 3. Comparison of the experimental vibrational progressions found for THF for the neutral electronic ground states, the neutral electronic excited states with both present theoretical (MP2/aug-cc-pVDZ) and experimental vibrational progressions found for the ionic electronic ground state. Wavenumber are those of supplementary information table $2\left(\mathrm{in}^{-1}\right)$.

\begin{tabular}{|c|c|c|c|c|c|c|c|c|c|c|c|}
\hline \multirow[b]{2}{*}{ Mode } & \multicolumn{9}{|c|}{ Neutral } & \multicolumn{2}{|c|}{ Ionic } \\
\hline & $\begin{array}{c}\text { Ground } \\
\mathrm{A}^{\prime} / \mathrm{A}\end{array}$ & $\begin{array}{c}3 \mathrm{~s}\left(\mathrm{C}_{2}\right) \\
\mathrm{B}\end{array}$ & $\begin{array}{c}3 \mathrm{~s}\left(\mathrm{C}_{\mathrm{s}}\right) \\
\mathrm{A}^{\prime}\end{array}$ & $\begin{array}{c}3 \mathrm{p}\left(\mathrm{C}_{2}\right) \\
\mathrm{B}\end{array}$ & $\begin{array}{c}3 \mathrm{p}\left(\mathrm{C}_{\mathrm{s}}\right) \\
\mathrm{A}^{\prime}\end{array}$ & $\begin{array}{c}3 \mathrm{p}\left(\mathrm{C}_{\mathrm{s}}\right) \\
\mathrm{A}^{\prime \prime}\end{array}$ & $\begin{array}{c}3 \mathrm{p}\left(\mathrm{C}_{\mathrm{s}}\right) \\
\mathrm{A}^{\prime}\end{array}$ & $\begin{array}{c}3 \mathrm{~d}\left(\mathrm{C}_{2}\right) \\
\mathrm{B}\end{array}$ & $\begin{array}{c}3 \mathrm{~d}\left(\mathrm{C}_{2}\right) \\
\mathrm{B}\end{array}$ & $\begin{array}{c}\text { Theory } \\
\text { Ground } \\
\text { A/B }\end{array}$ & $\begin{array}{c}\text { Exp. } \\
\text { Ground } \\
\text { A / B }\end{array}$ \\
\hline$v_{33}$ & $39.5^{\mathrm{a}}$ & 62.9 & 171 & 183.9 & 79.8 & 136.3 & 185.5 & & & & \\
\hline$v_{17}$ & 286 & & 237 & & & & & & & & \\
\hline$v_{26}$ & 1244 & & & & & & & 1268.7 & 1296.9 & 1243.3 & 1234.0 \\
\hline$v_{32}$ & 591 & & & & & & & & $542.0^{\mathrm{b}}$ & 570.6 & $596.8^{b}$ \\
\hline$v_{11}$ & 1142 & & & & & & & & 1135.6 & 1042.1 & $1064.7^{b}$ \\
\hline
\end{tabular}

\footnotetext{
${ }^{\mathrm{a}}$ Estimation from Ref. $22 .{ }^{\mathrm{b}}$ Deduced from combinations, see text.
} 
Table 4. Rydberg series analysis. Energies in eV. Quantum defects are calculated according to the Rydberg formula, see text.

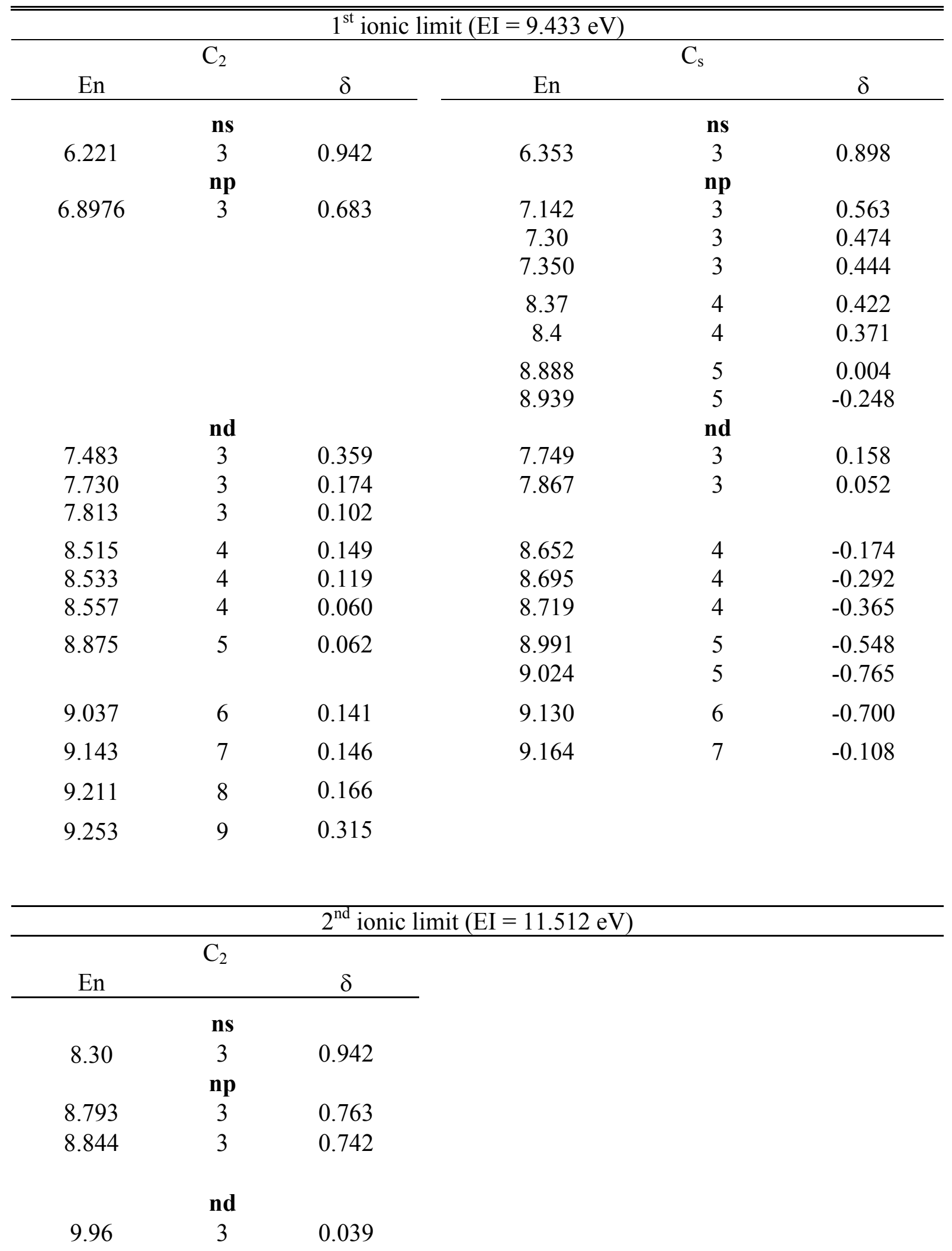




\begin{tabular}{|c|c|c|c|c|c|}
\hline \multicolumn{6}{|c|}{$3^{\text {rd }}$ ionic limit $(\mathrm{EI}=11.964 \mathrm{eV})$} \\
\hline \multicolumn{3}{|c|}{$\mathrm{C}_{2}$} & \multicolumn{3}{|c|}{$\mathrm{C}_{\mathrm{s}}$} \\
\hline \multirow[t]{2}{*}{ En } & & $\delta$ & En & & $\delta$ \\
\hline & ns & & & & \\
\hline \multirow[t]{3}{*}{8.965} & 3 & 0.870 & \multirow{2}{*}{\multicolumn{3}{|c|}{$\mathbf{n p}$}} \\
\hline & & & & & \\
\hline & & & 9.037 & 3 & 0.655 \\
\hline
\end{tabular}


Table 5. Calculated and experimental ionisation energies and band assignments for THF.

\begin{tabular}{|c|c|c|c|c|c|c|c|c|c|}
\hline \multicolumn{6}{|c|}{ Theory } & \multicolumn{4}{|c|}{ Experiment } \\
\hline \multicolumn{2}{|c|}{ This work } & \multicolumn{4}{|c|}{$\begin{array}{c}\text { Yang et al. } \\
{[25]}\end{array}$} & This work & $\begin{array}{c}\text { Yang et al. } \\
{[25]}\end{array}$ & $\begin{array}{c}\text { Kimura et al. } \\
{[48]}\end{array}$ & $\begin{array}{c}\text { Yamauchi et al. } \\
{[49]}\end{array}$ \\
\hline \multicolumn{2}{|c|}{ OVGF/aug-cc-pVDZ } & \multicolumn{2}{|c|}{ OVGF 6-31G* } & \multicolumn{2}{|c|}{ SAOP ET-PVQZ } & \multirow[t]{2}{*}{$\mathrm{PES}^{\mathrm{a}}$} & \multirow[t]{2}{*}{$\mathrm{EMS}^{\mathrm{b}}$} & \multirow[t]{2}{*}{ PES $^{b}$} & \multirow[t]{2}{*}{ PIS $^{\mathrm{c}}$} \\
\hline $\mathrm{C}_{2}$ & $\mathrm{C}_{\mathrm{s}}$ & $\mathrm{C}_{2}$ & $\mathrm{C}_{\mathrm{s}}$ & $\mathrm{C}_{2}$ & $\mathrm{C}_{\mathrm{s}}$ & & & & \\
\hline $9.94(9 b)$ & $9.91\left(12 \mathrm{a}^{\prime}\right)$ & 9.38 & 9.63 & $10.01(9 b)$ & $10.32\left(12 \mathrm{a}^{\prime}\right)$ & 9.718 & 9.7 & 9.74 & 9.67 \\
\hline $11.65(11 \mathrm{a})$ & 11.89 (8a") & 11.11 & 11.36 & $11.67(11 \mathrm{a})$ & 11.93 (11a') & 11.515 & 11.9 & 11.52 & 11.41 \\
\hline $12.20(10 \mathrm{a})$ & 11.65 (11a') & 11.85 & 11.65 & $12.11(10 a)$ & 11.97 (8a") & 11.964 & & & 11.99 \\
\hline $12.43(8 b)$ & 12.26 (7a") & 12.08 & 11.86 & $12.51(8 b)$ & 12.40 (7a") & 12.466 & & & 12.48 \\
\hline $12.62(9 a)$ & $12.30\left(10 \mathrm{a}^{\prime}\right)$ & 12.30 & 12.11 & $12.75(9 a)$ & 12.72 (6a") & 12.868 & & 12.52 & 12.90 \\
\hline $14.21(7 b)$ & 13.74 (6a") & 14.06 & 13.69 & $13.98(7 b)$ & 13.84 (9a') & 14.040 & 14.1 & 14.1 & 14.00 \\
\hline $14.82(6 b)$ & 14.49 (9a') & 14.72 & 14.28 & $14.48(8 \mathrm{a})$ & 14.23 (5a") & 14.430 & & 14.5 & 14.45 \\
\hline $14.95 \quad(8 a)$ & 15.29 (5a") & 14.72 & 15.13 & $14.76(6 b)$ & 15.12 (8a') & 15.271 & & 15.4 & 15.29 \\
\hline $16.57(7 a)$ & $16.29\left(8 a^{\prime}\right)$ & 16.54 & 16.15 & $16.22(7 a)$ & 15.99 (7a') & 16.246 & 16.3 & 16.8 & 16.70 \\
\hline \multirow[t]{2}{*}{$16.93(5 b)$} & $16.83\left(7 a^{\prime}\right)$ & 16.91 & 16.66 & $16.51(5 b)$ & 16.31 (4a") & & & & 16.70 \\
\hline & & & & $18.64(6 a)$ & 18.67 (6a') & & 19.3 & 19.5 & 19.42 \\
\hline
\end{tabular}

${ }^{\mathrm{a}} \mathrm{He}(\mathrm{I})$ Photoelectron spectroscopy, ${ }^{\mathrm{b}}$ Electron Momentum Spectroscopy, ${ }^{\mathrm{c}}$ Penning Ionisation Spectroscopy. 
Figure 1. (a) Structure of THF with atom numbering. (b) Pseudorotation of THF. Half of the cycle of the pseudorotation angle $\left(\phi=0\right.$ to $\left.180^{\circ}\right)$ is shown. Picture adapted from references 17 and 25.

(a)<smiles></smiles>

(b)

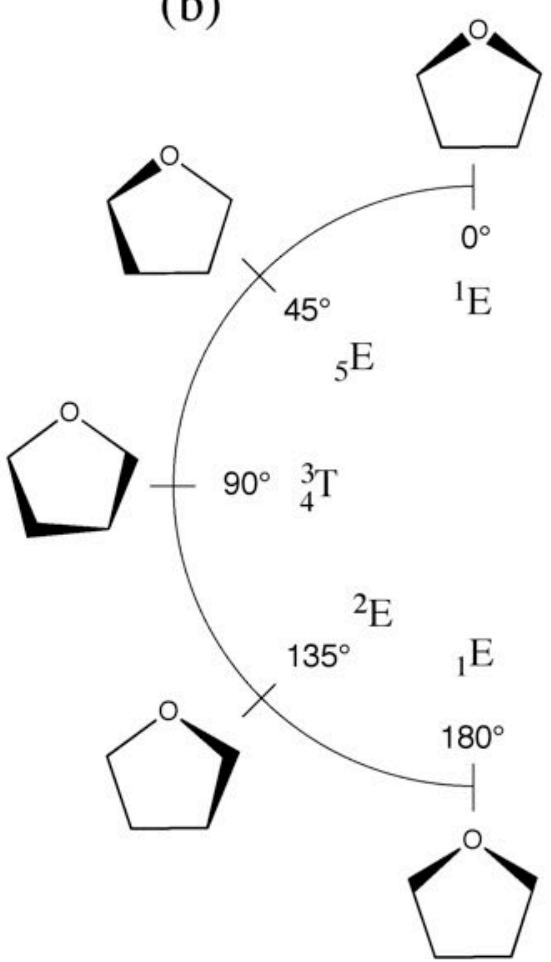


Figure 2. High-resolution photoabsorption spectrum (a) and electron energy loss spectrum (b) of THF recorded at $100 \mathrm{eV}$ and $10^{\circ}$ scattering angle.
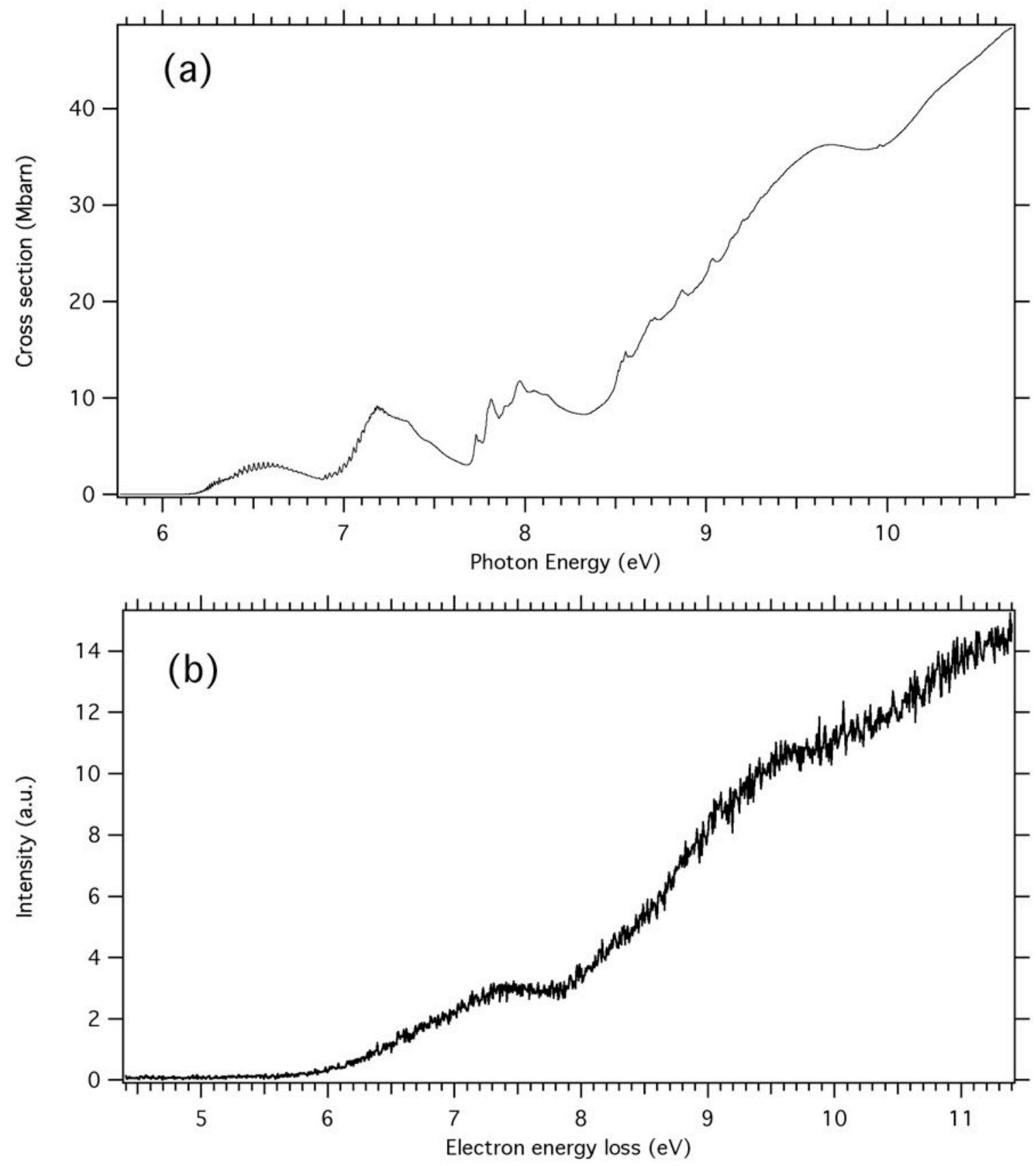
Figure 3. High-resolution photoabsorption spectrum of THF (full lines) and theoretical calculations (vertical lines). The circles refer to the $\mathrm{C}_{2}$ geometry and the triangles to the $\mathrm{C}_{\mathrm{s}}$ one. (a). Detail of the $3 \mathrm{~s}$ transition region and the associated vibrational progressions. (b) Detail of the $3 p$ and $3 d$ transitions and associated vibrational progressions. The trace of the first band of the photoelectron spectrum is shown in dots.
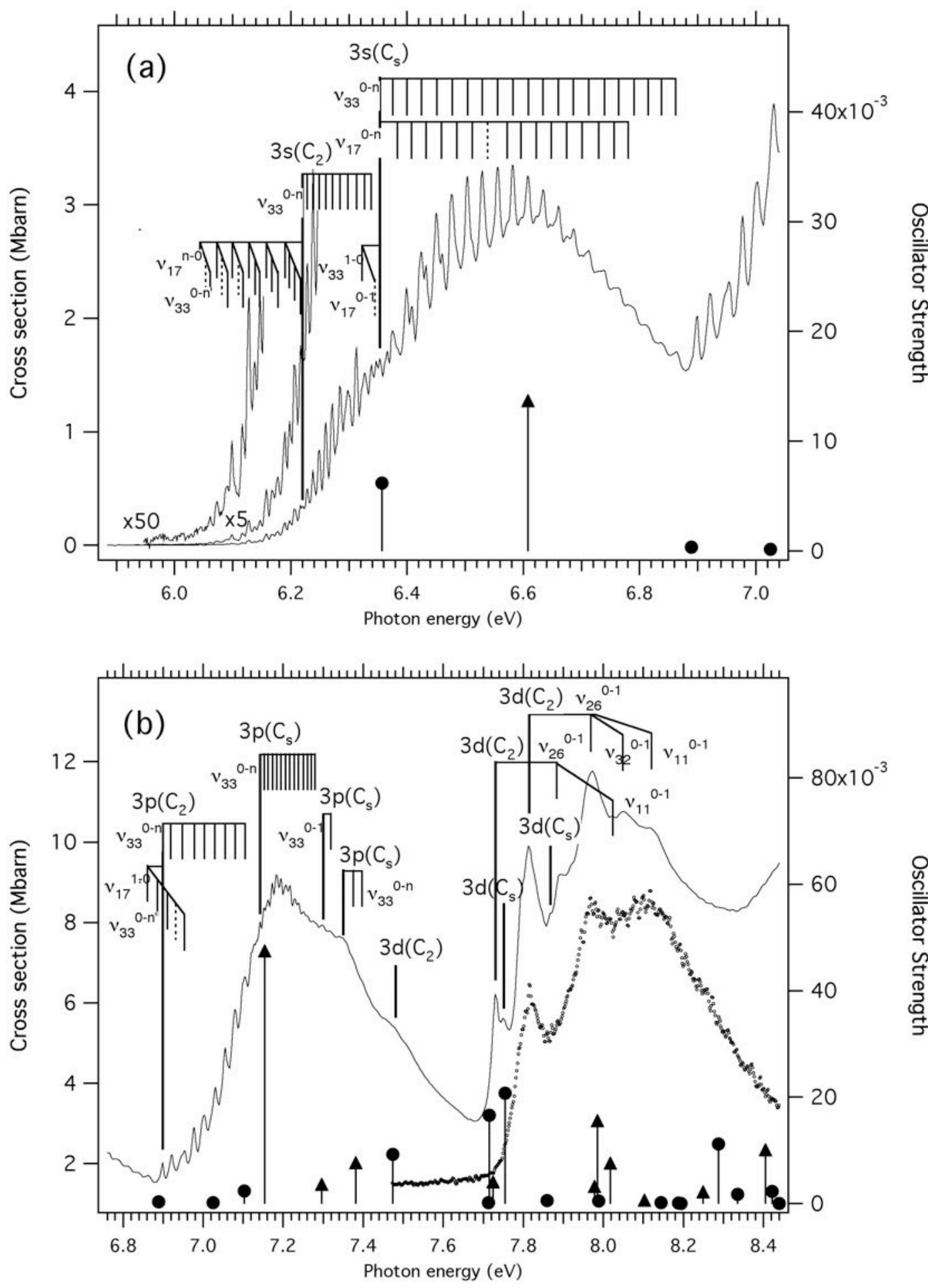
Figure 4. High-resolution photoabsorption spectrum of THF in the 8.2-10.6 eV showing Rydberg states and vibrational progressions.

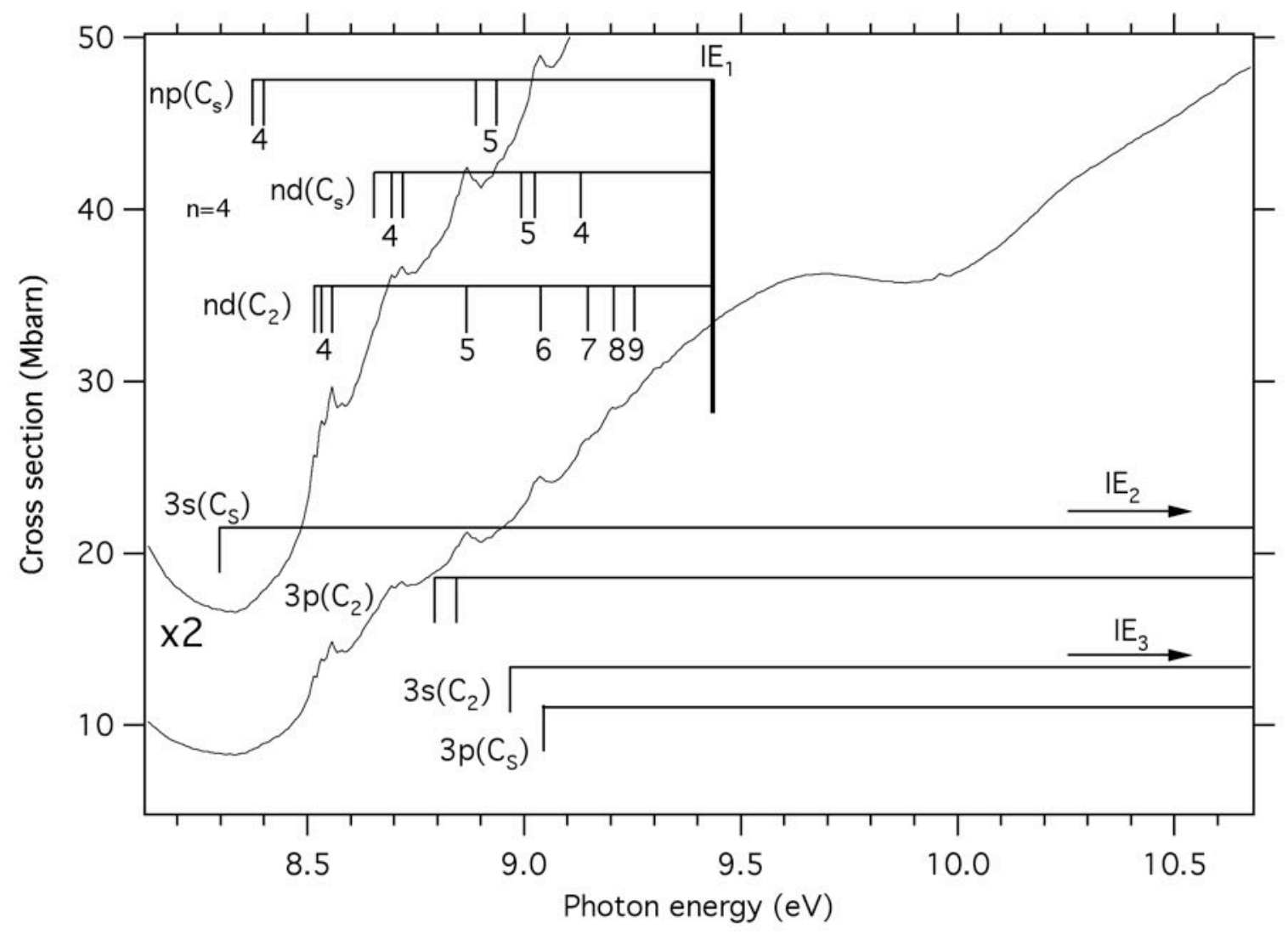


Figure 5. He(I) photoelectron spectrum of THF (a) in the 8-16 eV energy region, (b) detail of the first band in the 9.1-10.6 eV energy region.
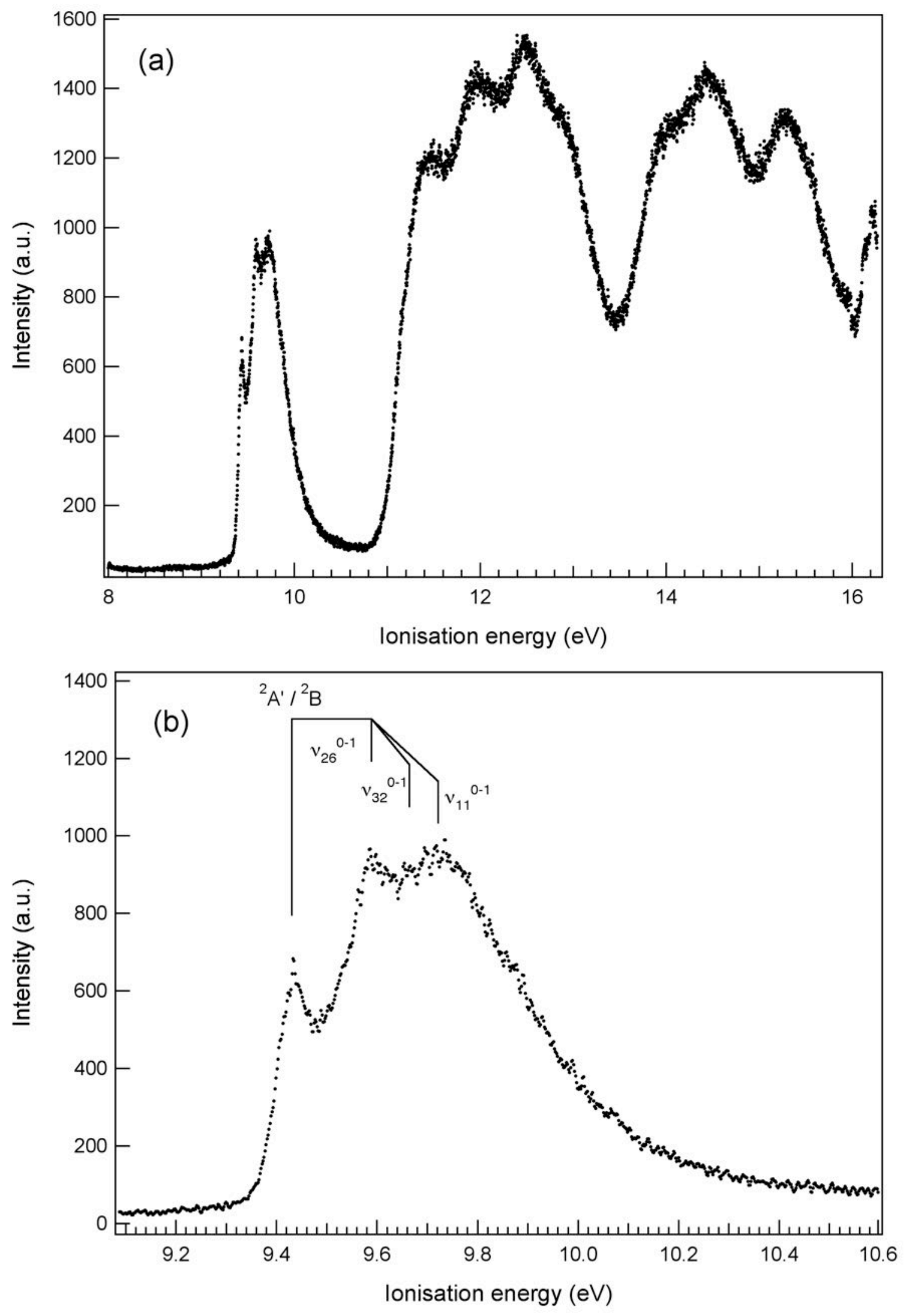


\section{Supplementary Information}

\section{Table captions}

Supplementary information table 1. Theoretical and experimental structural parameters for neutral and ionised tetrahydrofuran . Bond lengths and angles are in $\AA$ and degree, respectively.

Supplementary information table 2. Fundamental vibrational frequencies for $\mathrm{C}_{2}$ tetrahydrofuran.

Supplementary information table 3 . Vibrational structure in the $3 \mathrm{~s}$ band system $(6-6.8 \mathrm{eV})$.

Supplementary information table 4 . Vibrational structure in the $3 p$ band system $(6.8-7.4$ $\mathrm{eV})$.

Supplementary information table 5. Vibrational structure in the $3 \mathrm{~d}$ band system $(7.4-8.2$ $\mathrm{eV})$.

Supplementary information table 6. MP2/aug-cc-pVDZ harmonic vibrational frequencies for the ground ionic state of $\mathrm{C}_{2}$ and $\mathrm{C}_{2 \mathrm{v}}$ conformers of tetrahydrofuran .

Supplementary information table 7. Vibrational structure for the ionic ground state. 
Supplementary information table 1. Theoretical and experimental structural parameters for neutral and ionised tetrahydrofuran . Bond lengths and angles are in $\AA$ and degree, respectively.

\begin{tabular}{|c|c|c|c|c|c|c|c|c|c|c|c|c|c|}
\hline \multirow{4}{*}{ Parameter } & \multirow{3}{*}{\multicolumn{2}{|c|}{$\begin{array}{l}\text { Positive ion } \\
\text { UMP2 } \\
\text { aug-cc-pVDZ }\end{array}$}} & \multicolumn{11}{|c|}{ Neutral molecule } \\
\hline & & & \multirow{2}{*}{\multicolumn{2}{|c|}{$\begin{array}{c}\text { MP2 } \\
\text { aug-cc-pVDZ } \\
\text { This work }\end{array}$}} & \multirow{2}{*}{\multicolumn{2}{|c|}{$\begin{array}{l}\text { MP2 } \\
\text { 6-31G* } \\
\text { Ref. } 22\end{array}$}} & \multirow{2}{*}{\multicolumn{2}{|c|}{$\begin{array}{l}\text { B3LYP } \\
6-31 G^{* *} \\
\text { Ref. } 16\end{array}$}} & \multicolumn{2}{|c|}{$\begin{array}{c}\text { MP2 } \\
\text { g-cc-pVTZ }\end{array}$} & \multirow{2}{*}{$\begin{array}{l}\text { MW }^{\mathrm{a}} \\
\text { Ref. } 19\end{array}$} & & $\mathrm{ND}^{\mathrm{c}}$ \\
\hline & & & & & & & & & $\begin{array}{l}\text { Ig-cc } \\
\text { Ref }\end{array}$ & 24 & & Ref. 44 & Ref. 45 \\
\hline & $\mathrm{C}_{\mathrm{s}}$ & $\mathrm{C}_{2 \mathrm{v}}$ & $\mathrm{C}_{2}$ & $\mathrm{C}_{\mathrm{s}}$ & $\mathrm{C}_{2}$ & $\mathrm{C}_{\mathrm{s}}$ & $\mathrm{C}_{2}$ & $\mathrm{C}_{\mathrm{s}}$ & $\mathrm{C}_{2}$ & $\mathrm{C}_{\mathrm{s}}$ & $\mathrm{C}_{1}$ & $\mathrm{C}_{2}$ & $\mathrm{C}_{2}$ \\
\hline $\mathrm{O}_{1}-\mathrm{C}_{2}$ & 1.433 & 1.443 & 1.448 & 1.437 & 1.4353 & 1.4253 & 1.432 & 1.423 & 1.434 & 1.424 & 1.427 & $1.435(5)$ & $1.438(3)$ \\
\hline $\mathrm{C}_{2}-\mathrm{C}_{3}$ & 1.529 & 1.525 & 1.532 & 1.543 & 1.5258 & 1.5367 & 1.534 & 1.545 & 1.523 & 1.533 & $1.5519(27)$ & $1.531(10)$ & $1.516(3)$ \\
\hline $\mathrm{C}_{4}-\mathrm{C}_{5}$ & 1.529 & 1.525 & 1.532 & 1.543 & & & & & 1.523 & 1.533 & $1.5239(26)$ & & \\
\hline $\mathrm{C}_{3}-\mathrm{C}_{4}$ & 1.561 & 1.543 & 1.538 & 1.543 & 1.5280 & 1.5468 & 1.536 & 1.554 & 1.527 & 1.546 & $1.53324(69)$ & $1.531(10)$ & $1.516(3)$ \\
\hline $\mathrm{C}_{5}-\mathrm{H}_{8}$ & 1.110 & 1.116 & 1.101 & 1.098 & 1.0996 & 1.0928 & 1.096 & 1.093 & 1.094 & 1.097 & $1.09626(60)$ & $1.09(5)$ & $1.101(4){ }^{d}$ \\
\hline $\mathrm{C}_{5}-\mathrm{H}_{9}$ & 1.110 & 1.101 & 1.105 & 1.108 & 1.0952 & 1.1021 & 1.093 & 1.103 & 1.089 & 1.087 & $1.09372(60)$ & $1.09(5)$ & $1.094(4){ }^{\mathrm{d}}$ \\
\hline $\mathrm{C}_{4}-\mathrm{H}_{12}$ & 1.097 & 1.098 & 1.102 & 1.099 & 1.0942 & 1.0933 & 1.095 & 1.093 & 1.088 & 1.088 & 1.095 & $1.09(5)$ & $1.094(4)^{d}$ \\
\hline $\mathrm{C}_{4}-\mathrm{H}_{13}$ & 1.097 & 1.100 & 1.100 & 1.100 & 1.0957 & 1.0941 & 1.101 & 1.094 & 1.088 & 1.088 & 1.095 & $1.09(5)$ & $1.096(4)^{d}$ \\
\hline $\mathrm{C}_{2} \mathrm{O}_{1} \mathrm{C}_{5}$ & 112.02 & 109.93 & 109.17 & 103.98 & 109.30 & 104.10 & 109.9 & 105.5 & 109.33 & 104.07 & & $109.8(3)$ & $109.9(3)$ \\
\hline $\mathrm{O}_{1} \mathrm{C}_{2} \mathrm{C}_{3}$ & 108.52 & 106.25 & 106.10 & 105.34 & 106.17 & 105.34 & 106.5 & 105.7 & 106.09 & 105.37 & & $106.7(4)$ & $106.4(2)$ \\
\hline $\mathrm{C}_{2} \mathrm{C}_{3} \mathrm{C}_{4}$ & 105.47 & 101.87 & 101.17 & 103.25 & 101.12 & 103.19 & 101.5 & 103.3 & 101.09 & 103.17 & & $101.9(3)$ & $102.6(2)$ \\
\hline $\mathrm{O}_{1} \mathrm{C}_{2} \mathrm{H}_{8}$ & 103.09 & 101.03 & 108.94 & 107.58 & 109.32 & 109.98 & & & & & & & $108.1(2)$ \\
\hline $\mathrm{O}_{1} \mathrm{C}_{2} \mathrm{H}_{9}$ & 103.09 & 105.94 & 108.08 & 109.44 & 108.38 & 107.68 & & & & & & & $108.4(3)$ \\
\hline $\mathrm{C}_{2} \mathrm{O}_{1} \mathrm{C}_{5} \mathrm{C}_{4}$ & -12.01 & 0.00 & -12.95 & 42.55 & -12.88 & 42.58 & -12.0 & 40.2 & -12.96 & 42.60 & & $-11.7(3)$ & $-11.3(2)$ \\
\hline $\mathrm{O}_{1} \mathrm{C}_{2} \mathrm{C}_{3} \mathrm{C}_{4}$ & 30.47 & 0.00 & 33.07 & -25.33 & 32.94 & -25.30 & 30.8 & 23.7 & 33.08 & -25.32 & & $29.6(3)$ & $28.8(2)$ \\
\hline $\mathrm{C}_{2} \mathrm{C}_{3} \mathrm{C}_{4} \mathrm{C}_{5}$ & -36.45 & 0.00 & -39.35 & 0.00 & -39.07 & 0.00 & -36.5 & 0.0 & -39.31 & 0.00 & & $-35.2(4)$ & $-34.5(2)$ \\
\hline
\end{tabular}

${ }^{\mathrm{a}}$ Microwave spectroscopy. ${ }^{\mathrm{b}} \mathrm{X}$-Ray diffraction data at $148 \mathrm{~K} .{ }^{\mathrm{c}}$ High resolution neutron diffraction at $5 \mathrm{~K} .{ }^{\mathrm{d}}$ Bond length for CD, average geometrical parameters. 
Supplementary information table 2. Fundamental vibrational frequencies for $\mathrm{C}_{2}$ tetrahydrofuran.

\begin{tabular}{|c|c|c|c|}
\hline A symmetry & Description & $\begin{array}{c}\text { Wavenumber } \\
\left(\mathrm{cm}^{-1}\right)\end{array}$ & $\begin{array}{l}\text { Energy } \\
(\mathrm{meV})\end{array}$ \\
\hline$v_{1}$ & $\beta-\mathrm{CH}_{2}$ symmetric stretch & 2962 & 367.2 \\
\hline$v_{2}$ & $\alpha-\mathrm{CH}_{2}$ asymmetric stretch & 2941 & 364.6 \\
\hline$v_{3}$ & $\beta-\mathrm{CH}_{2}$ symmetric stretch & 2913 & 361.2 \\
\hline$v_{4}$ & $\alpha-\mathrm{CH}_{2}$ symmetric stretch & 2875 & 356.5 \\
\hline$v_{5}$ & $\alpha-$ and $\beta-\mathrm{CH}_{2}$ bend & 1488 & 184.5 \\
\hline$v_{6}$ & $\beta-\mathrm{CH}_{2}$ bend & 1462 & 181.3 \\
\hline$v_{7}$ & $\alpha-\mathrm{CH}_{2}$ wag & 1364 & 169.1 \\
\hline$v_{8}$ & $\beta-\mathrm{CH}_{2}$ wag $+\beta-\mathrm{CH}_{2}$ twist & 1308 & 162.2 \\
\hline$v_{9}$ & $\alpha-$ and $\beta-\mathrm{CH}_{2}$ twist & 1227 & 152.1 \\
\hline$v_{10}$ & $\beta-\mathrm{CH}_{2}$ twist $+\beta-\mathrm{CH}_{2}$ wag $+\ldots$ & 1178 & 146.1 \\
\hline$v_{11}$ & $\alpha-\mathrm{CH}_{2}$ rock $+\beta-\mathrm{CH}_{2}$ rock & 1142 & 141.6 \\
\hline$v_{12}$ & $\mathrm{C}_{\alpha} \mathrm{C}_{\beta}$ symmetric stretch $+\beta-\mathrm{CH}_{2}$ wag & 1029 & 127.6 \\
\hline$v_{13}$ & $\mathrm{C}_{\beta} \mathrm{C}_{\beta}$ stretch $+\mathrm{C}_{\alpha} \mathrm{C}_{\beta}$ symmetric stretch & 919 & 113.9 \\
\hline$v_{14}$ & COC symmetric stretch & 895 & 111.0 \\
\hline$v_{15}$ & $\beta$ - and $\alpha-\mathrm{CH}_{2}$ rock & 840 & 104.1 \\
\hline$v_{16}$ & Ring bend & 657 & 81.5 \\
\hline$v_{17}$ & Ring pucker & 286 & 35.5 \\
\hline \multicolumn{4}{|l|}{ B symmetry } \\
\hline$v_{18}$ & $\beta-\mathrm{CH}_{2}$ asymmetric stretch & 2972 & 368.5 \\
\hline$v_{19}$ & $\alpha-\mathrm{CH}_{2}$ asymmetric stretch & 2934 & 363.8 \\
\hline$v_{20}$ & $\beta-\mathrm{CH}_{2}$ symmetric stretch & 2912 & 361.0 \\
\hline$v_{21}$ & $\alpha-\mathrm{CH}_{2}$ symmetric stretch & 2858 & 354.3 \\
\hline$v_{22}$ & $\alpha-\mathrm{CH}_{2}$ bend & 1477 & 183.1 \\
\hline$v_{23}$ & $\beta-\mathrm{CH}_{2}$ bend & 1449 & 179.7 \\
\hline$v_{24}$ & $\alpha-$ and $\beta-\mathrm{CH}_{2}$ wag & 1334 & 165.4 \\
\hline$v_{25}$ & $\beta$ - and $\alpha-\mathrm{CH}_{2}$ wag & 1292 & 160.2 \\
\hline$v_{26}$ & $\beta$ - and $\alpha-\mathrm{CH}_{2}$ twist & 1244 & 154.2 \\
\hline$v_{27}$ & $\alpha-\mathrm{CH}_{2}$ twist $+\alpha-\mathrm{CH}_{2}$ rock & 1162 & 144.1 \\
\hline$v_{28}$ & COC asymmetric stretch & 1070 & 132.7 \\
\hline$v_{29}$ & $\beta-\mathrm{CH}_{2}$ rock $+\mathrm{C}_{\alpha} \mathrm{C}_{\beta}$ asymmetric stretch & 955 & 118.4 \\
\hline$v_{30}$ & $\mathrm{C}_{\alpha} \mathrm{C}_{\beta}$ asymmetric stretch $+\beta-\mathrm{CH}_{2}$ twist & 910 & 112.8 \\
\hline$v_{31}$ & $\beta-\mathrm{CH}_{2}$ rock + ring bend & 865 & 107.2 \\
\hline$v_{32}$ & Ring bend $+\beta-\mathrm{CH}_{2}$ rock & 591 & 73.3 \\
\hline$v_{33}$ & Ring pucker \& $\beta-\mathrm{CH}_{2}$ twist. Pseudo rotation. & $(39.5)^{\mathrm{a}}$ & $(5)$ \\
\hline
\end{tabular}

Assignments from Lepage et al. Ref. [4]

All frequencies taken from Ref. 22.

${ }^{\text {a }}$ Estimation of the pseudo rotational mode $v_{33}$ see Ref. 22 
Supplementary information table 3. Vibrational structure in the $3 \mathrm{~s}$ band system $(6-6.8 \mathrm{eV})$.

\begin{tabular}{|c|c|c|c|c|c|c|}
\hline \multirow{2}{*}{$\begin{array}{c}\text { Energy } \\
\text { eV }\end{array}$} & \multirow{2}{*}{$\begin{array}{c}\begin{array}{c}\text { Energy } \\
\text { difference }^{a} \\
\text { meV }\end{array}\end{array}$} & \multicolumn{2}{|c|}{$\begin{array}{l}\text { Vibrational } \\
\text { Spacing }\end{array}$} & \multirow{2}{*}{$\begin{array}{c}\text { Energy } \\
\text { Previous work } \\
\text { Ref. } 28 \\
\text { eV }\end{array}$} & \multirow{2}{*}{$\begin{array}{l}\text { Assignations } \\
\text { Previous work } \\
\text { Ref. } 28\end{array}$} & \multirow[t]{2}{*}{$\begin{array}{c}\text { Assignation } \\
\text { This work. }\end{array}$} \\
\hline & & $\mathrm{meV}$ & $\mathrm{cm}^{-1}$ & & & \\
\hline 6.043 & -177.4 & -29.6 & -238.7 & 6.047 & $v_{6}{ }^{0}$ & $v_{17}^{6-0}$ \\
\hline 6.061 & -159.7 & 15 & 121.0 & 6.061 & - & $v_{17}{ }^{6-0}+v_{33}{ }^{0-2}$ \\
\hline 6.073 & -147.8 & -25.4 & -204.7 & 6.071 & $v_{5}{ }^{0}$ & $v_{17}^{5-0}$ \\
\hline 6.091 & -129.9 & 17.9 & 144.4 & 6.090 & - & $v_{17}{ }^{5-0}+v_{33}{ }^{0-2}$ \\
\hline 6.099 & -122.4 & -28.6 & -230.7 & 6.100 & $v_{4}{ }^{0}$ & $v_{17}^{4-0}$ \\
\hline 6.117 & -104.4 & 18.0 & 145.2 & 6.117 & - & $v_{17}{ }^{4-0}+v_{33}{ }^{0-2}$ \\
\hline 6.127 & -93.8 & 30.5 & -246.0 & 6.129 & $v_{3}{ }^{0}$ & $v_{17}^{3-0}$ \\
\hline 6.138 & -83.2 & 10.6 & 85.49 & 6.136 & $v_{3}{ }^{1}$ & $v_{17}{ }^{3-0}+v_{33}{ }^{0-1}$ \\
\hline 6.147 & -74.0 & 9.2 & 74.20 & 6.146 & $v_{3}^{2}$ & $v_{17}{ }^{3-0}+v_{33}{ }^{0-2}$ \\
\hline 6.158 & -63.3 & -32.2 & -259.7 & 6.159 & $v_{2}{ }^{0}$ & $v_{17}^{2-0}$ \\
\hline 6.169 & -54.2 & 9.1 & 73.40 & 6.167 & $v_{2}{ }^{1}$ & $v_{17}{ }^{2-0}+v_{33}{ }^{0-1}$ \\
\hline 6.178 & -43.4 & 10.8 & 87.11 & 6.175 & $v_{2}^{2}$ & $v_{17}^{2-0}+v_{33}{ }^{0-2}$ \\
\hline 6.190 & -31.1 & -31.1 & -250.8 & 6.190 & $v_{1}^{0}$ & $v_{17}^{1-0}$ \\
\hline 6.198 & -23.3 & 7.8 & 62.91 & 6.198 & $v_{1}^{1}$ & $v_{17}^{1-0}+v_{33}{ }^{0-1}$ \\
\hline 6.207 & -14.0 & 9.3 & 75.01 & 6.207 & $v_{1}^{2}$ & $v_{17}{ }^{1-0}+v_{33}{ }^{0-2}$ \\
\hline 6.216 & -4.7 & 9.3 & 75.01 & 6.217 & $v_{1}^{3}$ & $v_{17}{ }^{1-0}+v_{33}{ }^{0-3}$ \\
\hline 6.221 & 0 & 0 & 0 & 6.222 & $0_{0}^{0}$ & $3 \mathrm{~s}\left(\mathrm{C}_{2}\right)$ \\
\hline & & & & 6.228 & $v_{1}^{4}$ & \\
\hline 6.229 & 7.8 & 7.8 & 62.91 & 6.230 & $v_{0}^{1}$ & $v_{33}{ }^{0-1}$ \\
\hline 6.238 & 17.2 & 9.4 & 75.82 & 6.239 & $v_{0}^{2}$ & $v_{33}{ }^{0-2}$ \\
\hline 6.249 & 28.2 & 11 & 88.72 & 6.249 & $v_{0}^{3}$ & $v_{33}{ }^{0-3}$ \\
\hline 6.260 & 39.3 & 11.1 & 89.53 & 6.260 & $v_{0}^{4}$ & $v_{33}{ }^{0-4}$ \\
\hline 6.271 & 42.5 & 11 & 88.72 & 6.272 & $v_{0}^{5}$ & $v_{33}{ }^{0-5}$ \\
\hline 6.284 & 63 & 12.7 & 102.4 & 6.285 & $v_{0}^{6}$ & $v_{33}{ }^{0-6}$ \\
\hline 6.298 & 77.4 & 14.4 & 116.1 & 6.297 & $v_{0}{ }^{7}$ & $v_{33}{ }^{0-7}$ \\
\hline 6.313 & 84 & 14.4 & 116.1 & 6.313 & $v_{0}^{8}$ & $v_{33}{ }^{0-8}$ \\
\hline 6.323 & -30.8 & -30.8 & -248.4 & & & $v_{17}^{1-0}$ \\
\hline 6.327 & 98.5 & 14.5 & 116.9 & 6.328 & $v_{0}{ }^{9}$ & $v_{33}{ }^{0-9}$ \\
\hline 6.339 & 117.7 & 11.4 & 91.95 & 6.343 & $v_{0}{ }^{10}$ & $v_{33}{ }^{0-10}$ \\
\hline 6.353 & 0 & 0 & 0 & & & $3 \mathrm{~s}\left(\mathrm{C}_{\mathrm{s}}\right)$ \\
\hline 6.375 & 21.2 & 21.2 & 171.0 & & & $v_{33}{ }^{0-1}$ \\
\hline 6.383 & 29.4 & 29.4 & 237.1 & & & $v_{17}^{0-1}$ \\
\hline 6.399 & 45.9 & 24.7 & 199.2 & & & $v_{33}{ }^{0-2}$ \\
\hline 6.409 & 55.8 & 26.4 & 212.9 & & & $v_{17}^{0-2}$ \\
\hline 6.424 & 70.8 & 24.9 & 200.8 & & & $v_{33}{ }^{0-3}$ \\
\hline 6.432 & 79.1 & 23.3 & 187.9 & & & $v_{17}^{0-3}$ \\
\hline 6.451 & 97.5 & 26.7 & 215.3 & & & $v_{33}{ }^{0-4}$ \\
\hline 6.461 & 107.6 & 28.5 & 229.8 & & & $v_{17}^{0-4}$ \\
\hline 6.476 & 122.8 & 25.3 & 204.1 & & & $v_{33}{ }^{0-5}$ \\
\hline
\end{tabular}




$\begin{array}{cccc}6.486 & 132.9 & 25.3 & 204.1 \\ 6.503 & 149.9 & 27.1 & 218.6 \\ 6.512 & 158.5 & 25.6 & 206.5 \\ 6.529 & 175.6 & 25.7 & 207.3 \\ 6.546 & 194.6 & 36.1 & 291.2 \\ 6.557 & 203.2 & 27.6 & 222.6 \\ 6.570 & 217.1 & 22.5 & 181.5 \\ 6.581 & 227.6 & 24.4 & 196.8 \\ 6.597 & 243.4 & 26.3 & 212.1 \\ 6.607 & 253.9 & 26.3 & 212.1 \\ 6.623 & 269.8 & 26.4 & 212.9 \\ 6.634 & 280.4 & 26.5 & 213.7 \\ 6.646 & 292.9 & 23.1 & 186.34 \\ 6.661 & 307.2 & 26.8 & 216.2 \\ 6.675 & 321.5 & 28.6 & 230.7 \\ 6.687 & 334.1 & 26.9 & 217.0 \\ 6.700 & 346.8 & 25.3 & 204.1 \\ 6.713 & 359.4 & 25.3 & 204.1 \\ 6.727 & 374 & 27.2 & 219.4 \\ 6.740 & 386.8 & 27.4 & 221.0 \\ 6.755 & 401.5 & 27.5 & 221.8 \\ 6.766 & 412.5 & 25.7 & 207.3 \\ 6.779 & 425.5 & 24 & 193.6 \\ 6.790 & 436.6 & 24.1 & 194.4 \\ 6.816 & 462.8 & 26.2 & 211.3 \\ 6.837 & 483.4 & 20.6 & 166.2 \\ 6.861 & 508 & 24.6 & 198.4\end{array}$

$$
\begin{aligned}
& v_{17}{ }^{0-5} \\
& v_{33}{ }^{0-6} \\
& v_{17}{ }^{0-6} \\
& v_{33}{ }^{0-7} \\
& v_{17}{ }^{0-7} \\
& v_{33}{ }^{0-8} \\
& v_{17}{ }^{0-8} \\
& v_{33}{ }^{0-9} \\
& v_{17}{ }^{0-9} \\
& v_{33}{ }^{0-10} \\
& v_{17}{ }^{0-10} \\
& v_{33}{ }^{0-11} \\
& v_{17}{ }^{0-11} \\
& v_{33}{ }^{0-12} \\
& v_{17}{ }^{0-12} \\
& v_{33}{ }^{0-13} \\
& v_{17}{ }^{0-13} \\
& v_{33}{ }^{0-14} \\
& v_{17}{ }^{0-14} \\
& v_{33}{ }^{0-15} \\
& v_{17}{ }^{0-15} \\
& v_{33}{ }^{0-16} \\
& v_{17}{ }^{0-16} \\
& v_{33}{ }^{0-17} \\
& v_{33}{ }^{0-18} \\
& v_{33}{ }^{0-19} \\
& v_{33}{ }^{0-20} \\
&
\end{aligned}
$$

${ }^{a}$ The energy difference is calculated with respect to the electronic origin. Negative value indicates a hot band. ${ }^{b}$ The vibrational spacing are the energy difference between two adjacent vibrational levels. Features from Ref. 28 labelled by — were reported in that work but not assigned. 
Supplementary information table 4 . Vibrational structure in the $3 p$ band system $(6.8-7.4$ eV).

Energy Energy difference Vibrational Spacing ${ }^{b} \quad$ Assignation

\begin{tabular}{|c|c|c|c|c|}
\hline $\mathrm{eV}$ & $\mathrm{meV}$ & $\mathrm{meV}$ & $\mathrm{cm}^{-1}$ & \\
\hline 6.863 & -34.4 & -34.4 & -277.5 & $v_{17}^{1-0}$ \\
\hline 6.890 & -7.7 & 26.7 & 215.3 & $v_{17}{ }^{1-0}+v_{33}{ }^{0-1}$ \\
\hline 6.898 & 0 & 0 & 0 & $3 p\left(C_{2}\right)$ \\
\hline 6.913 & 15.4 & 49.8 & 401.7 & $v_{17}{ }^{1-0}+v_{33}{ }^{0-2}$ \\
\hline 6.920 & 22.8 & 22.8 & 183.9 & $v_{33}{ }^{0-1}$ \\
\hline 6.945 & 47.4 & 24.6 & 198.4 & $v_{33}{ }^{0-2}$ \\
\hline 6.953 & 55.6 & 40.2 & 324.2 & $v_{17}^{1-0}+v_{33}^{0-4}$ \\
\hline 6.973 & 75 & 27.6 & 222.6 & $v_{33}{ }^{0-3}$ \\
\hline 7.001 & 103.2 & 28.2 & 227.4 & $v_{33}^{0-4}$ \\
\hline 7.030 & 132.7 & 29.5 & 237.9 & $v_{33}{ }^{0-5}$ \\
\hline 7.055 & 157.4 & 24.7 & 199.2 & $v_{33}{ }^{0-6}$ \\
\hline 7.080 & 182 & 24.6 & 198.4 & $v_{33}^{0-7}$ \\
\hline 7.105 & 207.5 & 25.5 & 205.7 & $v_{33}{ }^{0-8}$ \\
\hline 7.142 & 0 & 0 & 0 & $3 p\left(C_{s}\right)$ \\
\hline 7.152 & 9.9 & 9.9 & 79.8 & $v_{33}{ }^{0-1}$ \\
\hline 7.163 & 21.4 & 11.5 & 92.8 & $v_{33}{ }^{0-2}$ \\
\hline 7.173 & 31.2 & 9.8 & 79.0 & $v_{33}{ }^{0-3}$ \\
\hline 7.183 & 41.1 & 9.9 & 79.8 & $v_{33}^{0-4}$ \\
\hline 7.194 & 52.5 & 11.4 & 91.9 & $v_{33}{ }^{0-5}$ \\
\hline 7.206 & 64 & 11.5 & 92.8 & $v_{33}{ }^{0-6}$ \\
\hline 7.216 & 73.9 & 9.9 & 79.8 & $v_{33}{ }^{0-7}$ \\
\hline 7.227 & 85.4 & 11.5 & 92.7 & $v_{33}^{0-8}$ \\
\hline 7.237 & 95.2 & 9.8 & 79.0 & $v_{33}{ }^{0-9}$ \\
\hline 7.250 & 108.3 & 13.1 & 105.7 & $v_{33}{ }^{0-10}$ \\
\hline 7.259 & 117.1 & 8.8 & 71.0 & $v_{33}{ }^{0-11}$ \\
\hline 7.274 & 132 & 14.9 & 120.2 & $v_{33} 0-12$ \\
\hline 7.283 & 140.6 & 8.6 & 69.3 & $v_{33}{ }^{0-13}$ \\
\hline 7.3 & 0 & 0 & 0 & $3 p\left(C_{s}\right)$ \\
\hline 7.317 & 16.9 & 16.9 & 136.3 & $v_{33}{ }^{0-1}$ \\
\hline 7.350 & 0 & 0 & 0 & $3 p\left(C_{s}\right)$ \\
\hline 7.373 & 23 & 23 & 185.5 & $v_{33}{ }^{0-1}$ \\
\hline 7.396 & 46 & 23 & 185.5 & $v_{33}{ }^{0-2}$ \\
\hline
\end{tabular}

${ }^{\text {a }}$ The energy difference is calculated with respect to the electronic origin. Negative value indicates a hot band. ${ }^{b}$ The vibrational spacing are the energy difference between two adjacent vibrational levels. 
Supplementary information table 5. Vibrational structure in the $3 \mathrm{~d}$ band system $(7.4-8.2$ $\mathrm{eV})$.

\begin{tabular}{|c|c|c|c|c|}
\hline Energy & Energy difference & Vibrat & pacing $^{\mathrm{b}}$ & Assignation $^{a}$ \\
\hline $\mathrm{eV}$ & $\mathrm{meV}$ & $\mathrm{meV}$ & $\mathrm{cm}^{-1}$ & \\
\hline 7.730 & 0 & 0 & 0 & $3 \mathrm{~d}\left(\mathrm{C}_{2}\right)$ \\
\hline 7.813 & 0 & 0 & 0 & $3 \mathrm{~d}\left(\mathrm{C}_{2}\right)^{\prime}$ \\
\hline 7.887 & 157.3 & 157.3 & 1268.7 & $3 d\left(C_{2}\right)+v_{26}^{0-1}$ \\
\hline 7.973 & 160.8 & 160.8 & 1296.9 & $3 \mathrm{~d}\left(\mathrm{C}_{2}\right)^{\prime}+\mathrm{v}_{26}{ }^{0-1}$ \\
\hline 8.025 & 295.2 & 157.9 & 1273.5 & $3 d\left(C_{2}\right)+v_{26}{ }^{0-1}+v_{11}{ }^{0-1}$ \\
\hline 8.042 & 228 & 67.2 & 542.0 & $3 d\left(C_{2}\right)^{\prime}+v_{26}{ }^{0-1}+v_{32}{ }^{0-1}$ \\
\hline 8.114 & 301.6 & 384.4 & 3100.4 & $3 \mathrm{~d}\left(\mathrm{C}_{2}\right)^{\prime}+\mathrm{v}_{26}{ }^{0-1}+v_{11}{ }^{0-1}$ \\
\hline
\end{tabular}

${ }^{a}$ The energy difference is calculated with respect to the electronic origin. Negative value indicates a hot band. ${ }^{\mathrm{b}}$ The vibrational spacing are the energy difference between two adjacent vibrational levels. 
Supplementary information table 6. MP2/aug-cc-pVDZ harmonic vibrational frequencies for the ground ionic state of $\mathrm{C}_{2}$ and $\mathrm{C}_{2 \mathrm{v}}$ conformers of tetrahydrofuran .

\begin{tabular}{|c|c|c|c|c|c|}
\hline Species & $\begin{array}{c}\mathrm{C}_{2} \\
\text { Wavenumber } \\
\left(\mathrm{cm}^{-1}\right)\end{array}$ & $\begin{array}{c}\text { Energy } \\
(\mathrm{meV})\end{array}$ & Species & $\begin{array}{c}\mathrm{C}_{2 \mathrm{v}} \\
\text { Wavenumber } \\
\left(\mathrm{cm}^{-1}\right)\end{array}$ & $\begin{array}{c}\text { Energy } \\
(\mathrm{meV})\end{array}$ \\
\hline $\mathrm{A}$ & & & $\mathrm{A}_{1}$ & & \\
\hline$v_{1}$ & 3190.4 & 395.6 & $v_{1}$ & 3138.6 & 389.1 \\
\hline$v_{2}$ & 3141.5 & 389.5 & $v_{2}$ & 3013.5 & 373.6 \\
\hline$v_{3}$ & 3113.6 & 386.0 & $v_{3}$ & 1516.5 & 188.0 \\
\hline$v_{4}$ & 2955.7 & 366.5 & $v_{4}$ & 1333.2 & 165.3 \\
\hline$v_{5}$ & 1495.1 & 185.4 & $v_{5}$ & 1280.9 & 158.8 \\
\hline$v_{6}$ & 1390.3 & 172.4 & $v_{6}$ & 1396.5 & 173.1 \\
\hline$v_{7}$ & 1350.3 & 167.4 & $v_{7}$ & 1091.9 & 135.4 \\
\hline$v_{8}$ & 1333.2 & 165.3 & $v_{8}$ & 930.1 & 115.3 \\
\hline$v_{9}$ & 1188 & 147.3 & $v_{9}$ & 764.2 & 94.7 \\
\hline$v_{10}$ & 1174.9 & 145.7 & $v_{10}$ & 733 & 90.9 \\
\hline$v_{11}$ & 1042.1 & 129.2 & $\mathrm{~A}_{2}$ & & \\
\hline$v_{12}$ & 998.3 & 123.8 & $v_{11}$ & 3190.5 & 395.6 \\
\hline$v_{13}$ & 942.6 & 116.9 & $v_{12}$ & 3050.7 & 378.2 \\
\hline$v_{14}$ & 805.9 & 99.9 & $v_{13}$ & 1271.1 & 157.6 \\
\hline$v_{15}$ & 752.3 & 93.3 & $v_{14}$ & 1139.9 & 141.3 \\
\hline$v_{16}$ & 613.4 & 76.1 & $v_{15}$ & 1003.3 & 124.4 \\
\hline \multirow[t]{2}{*}{$v_{17}$} & 238.6 & 29.6 & $v_{16}$ & 646.1 & 80.1 \\
\hline & & & $v_{17}$ & i188.9 & $\mathrm{i} 23.4$ \\
\hline B & & & $\mathrm{B}_{1}$ & & \\
\hline$v_{18}$ & 3197.9 & 396.5 & $v_{18}$ & 3207.4 & 397.7 \\
\hline$v_{19}$ & 3143.5 & 389.7 & $v_{19}$ & 3057.1 & 379.0 \\
\hline$v_{20}$ & 3117.7 & 386.5 & $v_{20}$ & 1240 & 153.7 \\
\hline$v_{21}$ & 2949.3 & 365.72 & $v_{21}$ & 1198 & 148.5 \\
\hline$v_{22}$ & 1479.9 & 183.5 & $v_{22}$ & 905.1 & 112.2 \\
\hline$v_{23}$ & 1399.2 & 173.5 & $v_{23}$ & 734 & 91.0 \\
\hline$v_{24}$ & 1322.1 & 163.9 & $v_{24}$ & 83.6 & 10.4 \\
\hline$v_{25}$ & 1285.8 & 159.4 & & & \\
\hline$v_{26}$ & 1243.3 & 154.1 & $\mathrm{~B}_{2}$ & & \\
\hline$v_{27}$ & 1136.1 & 140.9 & $v_{25}$ & 3132.1 & 388.3 \\
\hline$v_{28}$ & 967.8 & 120.0 & $v_{26}$ & 2999.2 & 371.9 \\
\hline$v_{29}$ & 905.3 & 112.2 & $v_{27}$ & 1491.8 & 185.0 \\
\hline$v_{30}$ & 887.3 & 110.0 & $v_{28}$ & 1391.9 & 172.6 \\
\hline$v_{31}$ & 709.9 & 88.0 & $v_{29}$ & 1341.8 & 166.4 \\
\hline$v_{32}$ & 570.6 & 70.7 & $v_{30}$ & 1275.4 & 158.1 \\
\hline \multirow[t]{3}{*}{$v_{33}$} & 213.8 & 26.5 & $v_{31}$ & 1009.2 & 125.1 \\
\hline & & & $v_{32}$ & 767 & 95.1 \\
\hline & & & $v_{33}$ & 694 & 86.0 \\
\hline
\end{tabular}


Supplementary information table 7. Vibrational structure for the ionic ground state.

\begin{tabular}{ccccc}
$\begin{array}{c}\text { Energy } \\
\mathrm{eV}\end{array}$ & $\begin{array}{c}\text { Energy difference } \\
\mathrm{meV}\end{array}$ & \multicolumn{2}{c}{$\begin{array}{c}\text { Vibrational Spacing } \\
\mathrm{meV}\end{array}$} & $\mathrm{cm}^{-1}$ \\
& & & & Assignation \\
9.433 & 0 & 0 & 0 & $0-0$ \\
9.586 & 153 & 153 & 1234.0 & $\mathrm{v}_{26}{ }^{0-1}$ \\
9.66 & 227 & 74 & 596.8 & $\mathrm{v}_{26}{ }^{0-1}+\mathrm{v}_{32}{ }^{0-1}$ \\
9.718 & 285 & 132 & 1064.7 & $\mathrm{v}_{26}{ }^{0-1}+\mathrm{v}_{11}{ }^{0-1}$
\end{tabular}

${ }^{a}$ The energy difference is calculated with respect to the electronic origin. 